\title{
The Schooling Decision: Family Preferences, Intergenerational Conflict, and Moral Hazard in the Brazilian Favelas
}

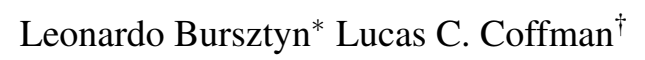

March 29, 2011

\begin{abstract}
This paper experimentally analyzes the schooling decisions of poor households with adolescent children in urban Brazil. Parents in our study were being paid large monthly transfers by the local government conditional upon their children attending school. We elicit parents' incentivized choices between such conditional monthly payments and guaranteed, unconditional monthly payments of varying relative sizes. In the baseline treatment, an overwhelming majority of parents prefer conditional transfers to larger unconditional transfers. However, parents reveal much weaker preferences for the conditionality if either (i) their child is not informed that the conditionality would be dropped or (ii) if parents are offered to receive free text-message notifications whenever their child misses school. These findings suggest important intergenerational conflicts in these schooling decisions and a lack of parental control and observability of school attendance. Further experimental treatments are consistent with parental preferences not just to keep the children in the classroom but also off the streets.
\end{abstract}

JEL Classification: C92, D13, D19, D82, I21, J13, O12

Keywords: Schooling, Intergenerational, Household, Development, Education, Experiments

\footnotetext{
*Contact: bursztyn@ucla.edu; UCLA Anderson School of Management, 110 Westwood Plaza, Los Angeles, CA 90095.

$\dagger$ Ohio State University.

We thank Philippe Aghion, Nava Ashraf, Eduardo Azevedo, Thomas Barrios, Max Bazerman, Davide Cantoni, Daniel Carvalho, Edward Glaeser, Itay Fainmesser, Bruno Ferman, Adam Guren, David Hemous, Larry Katz, Judd Kessler, Scott Kominers, Michael Kremer, David Laibson, Stephen Leider, Sendhil Mullainathan, Muriel Niederle, Alvin Roth, Andrei Shleifer, Josh Schwartzstein, Rodrigo Wagner, and Noam Yutchman, as well as seminar participants at Bocconi, Boston University, Brown, Chicago, Chicago Booth, Columbia, EPGE/FGV, Harvard, IIES Stockholm, INSPER, LSE, NEUDC 2009, Paris 1, PUC-Rio, Stanford GSB, UCLA Anderson, USP, and the World Bank for comments and suggestions. We also thank the World Bank, the Harvard Program on Negotiation and the Paul Warburg Funds for financial support, and Idalmo Freitas and Alexandre Magno for making the agreement with the Distrito Federal government possible.
} 


\section{Introduction}

Schooling decisions, arguably among the most important choices in a person's life, occur largely while the person is still a child and living with her parents. 1 However, economic models typically view intrahousehold dynamics and, particularly, parent-child conflict as a secondary element in the process $\mathrm{H}^{2}$ This paper examines the extent to which parent-child conflict and intrahousehold agency problems play a central role in schooling decisions of poor households with adolescent children in urban Brazil. In particular, we investigate how parental ability to monitor their children's school attendance behavior and the divergence in preferences for schooling across generations of the same household can be key factors in the decision-making process.

To study these issues, we look directly inside the household "black box". We analyze the preferences of adolescents and parents in poor, urban Brazil and the decision-making process that leads to real schooling choices. Based on the findings of a pilot experiment, we model the schooling decision as a moral hazard problem between a parent and her child, in which the child is the agent of the decision ${ }^{3}$ The parent values schooling more than the child does, but the parent cannot perfectly observe school attendance behavior. As a result, the parent's ability to incentivize her child to attend school is reduced. The parent will therefore be willing to pay for devices that either increase the incentives for the child to attend school or improve monitoring of the child's actions, thus attenuating moral hazard.

We use a novel experimental approach to elicit preferences and understand the informational structure within households with adolescent children in slums surrounding the city of Brasilia, Brazil. To incentivize the questions, we use the setup of the existing local conditional cash transfer (CCT) program, Bolsa-Escola Vida Melhor (roughly, "School Stipend, Better Life"). In the program, at the time of the intervention, families with monthly per capita household incomes below half of the Brazilian level of minimum wage (approximately US\$ 120 per month) ${ }_{4}^{4}$ received large monthly transfers, at least R \$ 120, conditional on their children attending school $85 \%$

\footnotetext{
${ }^{1}$ For the impact of schooling on income, see Angrist and Krueger (1991), Card (1995, 2001), and the surveys by Card (1999), Krueger and Lindahl (2001), and Goldin and Katz (2008), as well as Aghion and Howitt (2009) on the macroeconomics side. For schooling externalities, see Acemoglu and Angrist (2000). See Lochner and Moretti (2004) for the effect on criminal incarceration, Milligan, Moretti and Oreopoulos (2004) on political participation, and Lleras-Muney (2005) on mortality rates. In developing countries, see, for instance, Duflo (2001) and Psacharopoulos (1985, 1994), on returns to schooling, and Schultz (1997, 2002), on the effect of schooling on health and fertility.

${ }^{2}$ The standard approaches consider either a single decision-maker, as in human capital theory (following Becker, 1964), parents making the decision for their children (as in Becker, 1981), or dynasties with unified utility functions (following Barro, 1974). A few models consider intergenerational conflict in the analysis of schooling choices, generally viewing the parent as the agent making the decision who fails to fully internalize the child's benefit from schooling (see, for instance, the literature on child labor decisions, e.g., Baland and Robinson, 2000).

${ }^{3}$ The pilot experiment was intended to glean a general understanding of intrahousehold dynamics in the schooling decision and did not have this particular model in mind. For a discussion of the design and findings of the pilot, see the Supplemental Appendix to this paper.

${ }^{4}$ In a previous version of this paper, we referred to a lower level of the per capita income upper bound of R\$ 100 (approximately
} 
of days that month 5

In working with the Secretariat of Education of the Distrito Federal state $]^{6}$ we are able to estimate parents' willingness to pay to keep (or drop) the conditionality by offering them the opportunity to switch to unconditional monthly transfers of varying sizes delivered in the same manner as their current conditional payments. Across parents, we randomly change the conditions under which the choices are made. Parents are randomly assigned into one of four treatments, which are all described in detail below. Five percent of the subjects had one of their choices randomly chosen to be their actual payments from the local government between September and December 2009 for that child. By analyzing parents' choices under these real stakes, we elicit their preferences for schooling, the relevance of moral hazard problems inside the household, and shed light on their relative valuation of different benefits provided by school (such as safety and skills acquisition). Our goal is not to measure the impact of implementing different payment schemes chosen by the parents, but rather to understand, from parents' choices, the decision-making process leading to schooling choices in those households; our outcome variables of interest are therefore directly derived from parents' choices during the experiment, across treatments.

In the Baseline treatment, parents are asked to choose between their current CCT program and unconditional payments of varying relative sizes. They are told that their children would be informed of any program change. The vast majority of these parents (over 80 percent) prefer to keep the conditionality to tie the large cash transfer to their child's attendance, even if the unconditional transfers pay strictly more. Furthermore, on average, they are willing to forego the equivalent of more than six percent of their monthly household income to keep the conditionality.

That leaves the question of why the parents demand the conditionality, which we address with two other treatments (a summarized description and a comparison of all the treatments are found in Table 1, which also displays the research question that each treatment addresses and its implications for our argument). First, the results from the Don't Tell treatment suggest that parental preference for conditionality is driven by a need to control the children, indicating that preferences for schooling may differ across generations in the studied households. In that treatment, we offer parents the same menu of choices as in the Baseline treatment, but parents are told that their children will not be informed about their choice, or that parents were even offered such a choice. We observe a substantial drop in the number of parents preferring conditional payments in this group, US\$ 50), previously used by the local government.

${ }^{5}$ Although some CCT programs are said to suffer from enforcement, Bolsa-Escola Vida Melhor has a strong concern for enforcing the conditionality, which includes random visits of government officers to schools to check attendance and compliance to the rules.

${ }^{6}$ Contract number: Termo de Cooperacao N. 05/2009, Distrito Federal, Secretaria de Estado de Educacao. For a digital copy of the contract, see the Supplemental Appendix to this paper. 
relative to the baseline. Second, the results from the Text message treatment indicate that most parents believe they cannot control their children themselves because of a lack of monitoring. In that treatment, before eliciting parents' demand for the conditionality, they are offered the option of receiving free cell-phone text messages every time their child misses school, regardless of parents' choices between conditional and unconditional cash transfers. In this treatment, the child is aware of the parents' choice. Again, there is a significant decrease in the number of parents preferring to keep the conditionality, relative to the Baseline treatment. When parents are given the ability to perfectly monitor their children, the vast majority find the conditionality to be unnecessary.

These treatments provide evidence that, unlike conventional analyses of schooling decisions, family conflict can play a crucial role: parents are willing to pay substantial sums to have a device to control the actions of their child and increase the probability of their school attendance. Furthermore, the results suggest that low investment in education in those households would be more a consequence of the child's preferences rather than the parent's decision to keep the child out of school.

Under the same experimental setup, we also shed light on what drives parental demand to control school attendance. The results from our baseline treatment indicate a high parental valuation of schooling. However, it is unclear the extent to which this valuation is driven by skills acquisition in school or perhaps the non-classroom content of schooling (such as keeping the child off the streets). The Non-classroom treatment exploits the fact that public schools in the area we study offer a student classes during either a morning or an afternoon shift, but not both. In this treatment group, parents are offered the same choice between conditional and unconditional payments. The conditionality, however, is now on the child being in school during the shift in which the child has no classes, with no obligation to attend class. The requirement for the no-class shift is just to be on the school grounds (typically unambiguously defined by large walls and locked gates). There are no classes being offered, but the child can do whatever he or she likes, like playing sports. This treatment therefore incentivizes the child to be at school but removes the conditionality on classroom attendance. In this treatment, the willingness to pay for the conditionality remains high, although less than in the Baseline, indicating parents substantially value the non-classroom content of schooling.

These results could have important policy implications, particularly in developing countries such as Brazil, where educational attainment and school attendance are low despite the high levels of returns to schooling in that country. 7 In 2008, $10 \%$ of the Brazilian population were illiterate, and the average number of years of schooling was 7.1 (PNAD, 2008). This could lead an observer to believe, based on the standard model of

\footnotetext{
${ }^{7}$ The average wage of someone with a high-school (university) degree in Brazil is 116 (340) percent higher than that of someone with no schooling (PNAD, 2007).
} 
schooling, that poor parents do not value education or cannot afford to send their children to attend school because they need the children to provide resources for the household ${ }^{8}$ Our results suggest that there might be a further reason behind these unfortunate facts in the developing world: agency issues in the household. Our findings suggest that providing parents with improved information and monitoring on their children's actions could be an effective policy option to increase school attendance in areas of urban poverty 9910

This paper relates to several recent empirical studies on household decision-making, especially in the context of developing countries 11 In particular, Berry (2009) provides evidence of a differential impact of incentives for test scores and attendance depending on whether the recipient is the parent or the child, and depending on characteristics of the parent, such as the parent's level of education and time availability. Ashraf (2009) looks at the effect of spousal observability, communication and control on financial choices of married individuals in the Philippines. Our paper adds to the literature by providing direct experimental evidence on the importance of intergenerational agency issues, in particular with respect to the schooling decision.

On the theoretical side, this paper relates to the literature on intergenerational incentives within the family. Many of the current models can be traced back to Becker's (1974) "Rotten Kid Theorem". The famous result is that, absent informational asymmetries, an altruistic parent can control her child's actions indirectly through transfers if the child's actions affect the level of household income. The result does not necessarily hold under assumptions of moral hazard (Bergstrom, 1989, Weinberg 2001, and Gatti, 2005) ${ }^{12}$ The fact that the vast majority of parents in our setting want to pay for a device to induce their child to go to school suggests that the "Rotten Kid Theorem" might not hold for the schooling decision in the environment we study. However, our results also indicate that conditional cash transfers such as the ones under the Bolsa-Escola program might

\footnotetext{
${ }^{8}$ See for instance Basu and Van (1997), and Basu and Tzannatos (2006).

${ }^{9}$ The 2006 Brazilian National Household Survey (PNAD) asked 15-17 year-old adolescents about their main reason for not attending school: $39.1 \%$ reported their pure own lack of interest in going to school, $20.7 \%$ mentioned to be working or looking for a job, $3.7 \%$ reported to have to help at home, and only $1.5 \%$ reported that they were prevented from attending by their parents.

${ }^{10}$ These findings are consistent with recent work in the literature. Jensen (2010) provides evidence that in the Dominican Republic the perceived returns to schooling by eighth-grade students are significantly lower than the actual returns. Moreover, when provided with information on actual returns to schooling, the least-poor students in Jensen's analysis were significantly less likely to drop out of school in subsequent years. Attanasio and Kaufmann (2009) use data from a Mexican household survey and provide evidence that mothers have significantly higher expectations on returns to high school than their children in junior high school do. Dinkelman and Martínez (2011) find significant decreases in absenteeism from providing Chilean eighth graders and a subset of their parents with information about financial aid for higher education.

${ }^{11}$ Several of them address decision-making processes across spouses and genders, such as Duflo (2003), Duflo and Udry (2004), and Rangel (2006). Bobonis (2009) tests whether the allocation of resources in households is efficient, using experimental variation in Mexico. Some papers have also addressed empirically or experimentally issues on intergenerational decision-making, such as Li et al. (2010).

${ }^{12}$ Furthermore, Becker's theorem is limited to cases in which the utility of the parents and children are entirely driven by monetary outcomes, as shown by Bernheim et al. (1985). Banerjee (2004) provides a review of alternative ways to model education decision making by families. Chiappori (1992) and Browning and Chiappori (1998) provide a collective model of the household. Lizzeri and Siniscalchi (2008) characterize optimal parenting policies in a model of parental guidance and supervised learning. Cherchye et al. (2009) test general collective consumption models and reject the standard unitary model.
} 
reestablish the conditions for the theorem to hold and that parents' beliefs in our study are consistent with the theorem.

Finally, our paper adds to the literature on conditional cash transfers ${ }^{13}$ Conditional cash transfer programs are a widespread phenomenon in developing countries: in 2010, over thirty countries currently adopt this type of social program. The literature usually values conditional cash transfers to the extent that they achieve more and better-targeted redistribution when compared to an exclusive public goods provision policy 14 or because they might commit parents to keep their children in school ${ }^{15}$ We extend the literature by looking at the family's demand for the conditionality and find an alternative rationale for adopting CCT programs: parents actually prefer conditional to unconditional payments because the conditionality provides parents with the ability to induce school attendance by their children ${ }^{16}$

\section{Public education and conditional cash transfers in Brazil}

Education is compulsory in Brazil for children aged six to fifteen, but the law is loosely enforced. In fact, according to the 2006 Brazilian National Household Survey (PNAD), over 9\% of fourteen year-old children from the bottom quartile of the distribution of household per capita income report not being enrolled at the time of the survey. This hides an even larger attendance problem, since only enrollment is compulsory in Brazil. Large numbers of children drop out of school during the school year and re-enroll in the following year as required by law (de Janvry et al, 2007).

The problem of school attendance in Brazil is particularly acute for poor children aged thirteen to fifteen. Although working is only legal at the age of sixteen, over $15 \%$ of fifteen year-old children from the bottomquartile households in the income distribution were not enrolled in school in 2006, and over $22 \%$ reported to have a job during the week they were interviewed for the 2006 PNAD.

\footnotetext{
${ }^{13}$ For the impact of such programs on school attendance, see Parker, Rubalcava and Teruel (2008), Schultz (2004), Bourgignon et al. (2003), Glewwe and Olinto (2004), Finan and Bobonis (2009), Angelucci, De Giorgi, Rangel, and Rasul (forthcoming), and specifically for Brazil, de Janvry, Finan and Sadoulet (2007), and Glewwe and Kassouf (2008). For the effect on child labor, see Cardoso and Souza (2004). For the impact of incentivizing the child directly, see Kremer, Miguel and Thornton (2004), Angrist and Lavy (2009), and Jackson (2008). For indirect effects on the consumption of non-eligibles' consumption, see Angelucci and De Giorgi (2009). For the effect on sexual behavior of recipient children, see Baird, Chirwa, McIntosh, and Ozler (2009). For the analysis of the effect variations on the design of a conditional cash transfer program and intrahousehold externalities of the program, see Barrera-Osorio, Bertrand, Linden, and Perez-Calle (2008), and Baird, McIntosh, and Ozler (2009). For the effect of CCTs on child labor supply when the household is exposed to shocks, see de Janvry, Finan, Sadoulet, and Vakis (2006).

${ }^{14}$ See Gahvari and Mattos (2007), following arguments made by Besley and Coate (1992) and Zeckhauser (1971).

${ }^{15}$ See the World Bank report by Fiszbein et al. (2009) for a summary of the arguments in favor of conditional cash transfers. See de Janvry and Sadoulet (2006) for a discussion of unconditional versus conditional cash transfer programs.

${ }^{16}$ A related literature studies private responses to public transfers (e.g., Moffitt, 1992, and Rosenzweig and Wolpin, 1994).
} 
Since 1995, both local and federal governments in Brazil have implemented different conditional cash transfer (CCT) programs aimed at reducing income inequality and increasing school attendance. The idea of those programs is to make payments to families that meet some eligibility criteria (typically having a low level of per capita income in the household) but only if they meet some conditionality (usually a minimum level of monthly school attendance of their children). The first such program was Bolsa Escola, which was introduced in 1995 in the Distrito Federal state, which surrounds the Brazilian capital, Brasilia. It has been running with a few changes ever since then (it was renamed Bolsa-Escola Vida Melhor in 2009). In 1998, the federal government implemented the Bolsa-Escola program nationwide. In 2003, the federal program was redesigned and renamed Bolsa-Familia, targeting poor families with children aged six to fifteen.

The available evidence suggests that the federal program has indeed stimulated schooling among its beneficiaries. De Janvry et al (2007) estimate that in 261 municipalities in the Northeast of Brazil the program reduced dropout rates by $8 \%$ on average. They estimate that if the beneficiary children were not in the program, the dropout rate would have been $12 \%$ instead of the $4 \%$ currently observed among them. The program is thus estimated to have induced a $66 \%$ decline in dropout. The impact on school attendance rates is likely to have been higher since enrollment itself is compulsory (and therefore very high) regardless of the program.

Our analysis focuses on the Bolsa-Escola program in the areas surrounding Brasilia, and which, in 2009, was still administered separately by the local government.

At the time of our study, the eligibility criterion for the Bolsa-Escola program was a monthly per capita household income below half of the Brazilian level of minimum wage (approximately US\$ 120 per month). Under this CCT program, the mother of a beneficiary household receives $\mathrm{R} \$ 120$ per month if one child between the ages of six and fifteen attends a minimum of $85 \%$ of classes that month ${ }^{17}$ If the child misses more than $15 \%$ of the classes in any month (unjustified absences), payments are suspended for the next month onwards. 18 Absences are reported by teachers to the school principals and from them to the local government. Although anecdotal evidence suggests that in the national program the conditionality is not strongly enforced, the local program in the DF state is known for having a strong concern for enforcing the conditionality. The local government does random visits schools to enforce the compliance to the rules. If the family has more than one child within this age range, they receive $\mathrm{R} \$ 120$ per month for the first child, $\mathrm{R} \$ 30$ for the second, and $\mathrm{R} \$ 30$ for the third 19 The maximum payment per month is $\mathrm{R} \$ 180$ per family.

\footnotetext{
${ }^{17}$ If the household has no mother, the payment is made to the father or another adult responsible for the children.

${ }^{18}$ The only requirement that the child has to meet for the payment to be made to the family is the school-attendance requirement.

${ }^{19} \mathrm{~A}$ family would receive $\mathrm{R} \$ 0$ if any child missed more than $15 \%$ of days that month. Our experiment only potentially removed a conditionality worth $\mathrm{R} \$ 120$ from the child present.
} 


\section{Theoretical framework}

To organize our analysis and understand the treatments within a framework, we develop a simple model of the schooling decision in the household, which is viewed as a binary-choice moral hazard problem involving one child (the agent of the choice) and one parent.

\subsection{The model}

In the model, the child decides whether or not to go to school ( $S=1$, if she goes, and $S=0$ otherwise). If the child goes to school, the parent observes so with certainty. If the child misses school, the parent observes the child's true action with probability $\pi 2^{20}$

\subsubsection{Timeline}

1. The parent announces a binding contract before the child chooses $S$ : an income transfer $x_{0}$ if the parent observes that the child misses school, and $x_{1}$, otherwise. We assume the parent is able to commit to an ex-ante optimal announced contract 21

2. The child chooses $S$.

3. Transfer $x_{0}$ or $x_{1}$ is made from the parent to the child. We assume that the child consumes the transfer entirely on a private good of price one, and that the parent allocates what is left from household income $Y$ after the transfer to the consumption of the same good.

\subsubsection{Preferences}

For simplicity, we assume that the child's utility, $U^{\text {child }}$, is linear in the consumption of the private good. The child's utility also includes her net benefit from going to school in case she attends school. This benefit corresponds to the difference between the child's perceived gross benefit from attending school ( $V^{\text {child }}$ ) and her perceived cost $(\gamma)$. We assume that this difference is negative so the child faces a net private cost of

\footnotetext{
${ }^{20} \mathrm{We}$ assume that lack of observability only occurs when the child misses school because we think this assumption is more realistic than supposing lack of observability in both school attendance and absence actions. Our results hold if we assume lack observability in both actions instead.

${ }^{21}$ The Don't Tell treatment provides evidence consistent with this assumption.
} 
attending school, $c \equiv \gamma-V^{\text {child }}>0$. In the results section, we provide experimental evidence consistent with this assumption.

Letting $I_{S=j}$ be the indicator that the child chooses $S=j$, we can write the expected utility of the child as:

$$
E\left[U^{\text {child }}\right]=I_{S=1}\left\{x_{1}-c\right\}+I_{S=0}\left\{\pi x_{0}+(1-\pi) x_{1}\right\}
$$

Thus the child will choose to go to school if (child's incentive compatibility constraint):

$$
x_{1}-x_{0} \geq c / \pi
$$

The parent is assumed to be altruistic toward her child but discounts her child's utility by $\alpha \in[0,1){ }^{22}$ Finally, we assume that the parent derives a net private benefit $V>0$ from her child going to school. One reason why the parent faces a net private benefit of the child attending school while the child faces a net cost could be that the child faces a higher private cost of attending school than the parent (which could be combined with a lower perception of the gross benefit of attending school by the child) 23 Our Baseline treatment provides evidence consistent with the assumption that $V>0$.

The parent's expected utility is thus:

$$
E\left[U^{\text {parent }}\right]=I_{S=1}\left\{\left(Y-x_{1}\right)+\alpha\left(x_{1}-c\right)+V\right\}+I_{S=0}\left\{\pi\left[\left(Y-x_{0}\right)+\alpha x_{0}\right]+(1-\pi)\left[\left(Y-x_{1}\right)+\alpha x_{1}\right]\right\} .
$$

If the child goes to school $(S=1)$, the parent pays $x_{1}$ to the child and derives $V$ from her child attending school. The child in this case pays her private cost of school attendance $c$, which is discounted by $\alpha$ in the parentıs utility. If the child does not go to school $(S=0)$, with probability $\pi$ the parent pays $x_{0}$ to the child, and with probability $(1-\pi)$ the parent pays $x_{1}$. In either case, the parent does not derive benefit from school attendance, and the child does not pay the cost of school attendance.

\footnotetext{
${ }^{22}$ We impose imperfect altruism because $\alpha=1$ would imply the parent is indifferent between her own and her child's consumption, leaving no role for the provision of incentives through contingent transfers to the child.

${ }^{23}$ In our results section, we provide evidence that in our studied sample children have lower perceptions of the returns to schooling than their parents do.
} 


\subsubsection{Equilibrium outcomes - Does the child attend school?}

Solving for the equilibrium outcomes, we can establish:

Proposition 1 Let $\bar{Y} \equiv c / \pi$ and $\bar{V} \equiv(\alpha+(1-\alpha) / \pi) c$. Then:

1. If $Y<\bar{Y}$, then $x_{1}^{*}=0, x_{0}^{*}=0$ and $S^{*}=0$.

2. If $Y \geq \bar{Y}$, then:

(a) If $V \geq \bar{V}$, then $x_{1}^{*}=c / \pi, x_{0}^{*}=0$ and $S^{*}=1$.

(b) If $V<\bar{V}$, then $x_{1}^{*}=0, x_{0}^{*}=0$ and $S^{*}=0$.

Proof: see the Supplemental Appendix.

The first part of the proposition states that if the level of household income is below the minimum level of transfers to the child that induces school attendance, the child will not attend school, and the parent will not transfer any resources to the child. The second part states that if the level of household income is above that minimum level, the parent can induce school attendance, but only chooses to do so if it is ex-ante optimal for herself (i.e. $V \geq \bar{V}$ ).

Corollary 1: The role of monitoring: $\partial \bar{V} / \partial \pi<0$ and $\partial x_{1}^{*} / \partial \pi<0$.

The lower is the probability of observing the child's action, the higher has to be the transfer $x_{1}$ to induce school attendance, and the higher is the minimum level of parental valuation of schooling such that is is ex-ante optimal for the parent to induce attendance $(\bar{V})$.

\subsection{The experiment}

Suppose the parent is offered choices between two policy instruments: conditional cash transfers and (unconditional) cash transfers both of varying sizes. Conditional cash transfers are only paid to the parent if the child attends school whereas cash transfers are paid with certainty.

Definition 1 A conditional cash transfer $C C T\left(T_{C C T}\right)$ is a payment scheme that transfers $T_{C C T}$ units of income to the parent if $S=1$ and zero otherwise. Therefore, under this scheme, $\pi_{C C T}=1$, since the parent observes 
with certainty the child's action ${ }^{24}$

Definition $2 A$ cash transfer $C T\left(T_{C T}\right)$ is a payment scheme that transfers $T_{C T}$ units of income to the parent for any value of $S$. Therefore, under this scheme, the parent's level of observability is unchanged: $\pi_{C T}=\pi$.

In our experiment, we want to derive the size of a cash transfer, $\bar{T}_{C T}$, that would make the parent indifferent to a conditional cash transfer of size $\bar{T}_{C C T}$. Let us assume that all transfers sizes are larger than $\underline{T} \equiv \bar{Y}-Y$, so that the level of household income is always above the minimum level of transfers to the child that induces school attendance.

Proposition 2 CCTs and monitoring:

1. If $V<c$, then $\bar{T}_{C T} \leq \bar{T}_{C C T}$.

2. If $V=c$, then $\bar{T}_{C T}=\bar{T}_{C C T}$.

3. If $V>c$, then:

(a) If $\pi_{C T}<1$, then $\bar{T}_{C T}>\bar{T}_{C C T}$.

(b) If $\pi_{C T}=1$, then $\bar{T}_{C T}=\bar{T}_{C C T}$.

Proof: see the Supplemental Appendix.

Of most interest, is the third piece of the proposition. If the parent cannot perfectly observe the child's attendance behavior under a cash transfer scheme $\left(\pi_{C T}<1\right)$, and if the parent sufficiently values the child's schooling $(V>c)$, then the parent is willing to pay for the conditionality as a monitoring device (she prefers a CCT to a CT that pays strictly more) ${ }^{25}$ Also, since there is only one case for which $\bar{T}_{C T}>\bar{T}_{C C T}$, if this is observed in the experiment, this suggests that both $V>c$ and $\pi_{C T}<1$.

\footnotetext{
${ }^{24}$ In the actual setup that we study, the conditionality is a monthly $85 \%$ attendance rate. However, given the structure of the model, we assume for simplicity that the parent observes the child's action with certainty under the CCT scheme.

${ }^{25}$ If the child cares about the level of household income, another channel other than increasing monitoring through which conditional cash transfers can induce school attendance is given by the fact that payments to the parent are conditional on school attendance. As an example, if the parent consumes her fraction of household income on a household public good which the child can also consume, then the CCT creates wedge a in the consumption level of the household public good depending on the child's action, which is internalized by the child, thus increasing her incentives for school attendance. We do not detect this specific channel in our experiment and we also provide evidence that the bulk of the preference for conditionality is due to the monitoring feature of the CCT.
} 
In the next sections of the paper, we use a setup in which parents report their choices between conditional and unconditional cash transfers both of varying relative sizes. To map theoretical assumptions and predictions to experimental tests over a heterogeneous population, we make the simplifying assumption that there exists only one source of heterogeneity within the families in our study. We assume that those families vary according to parental net private benefit of the child going to school, $V$, which we suppose to be symmetrically distributed with mean $\hat{V}$ and cumulative distribution function $\psi\left(\right.$.). We also assume that $\pi_{C T}<1$. This implies that $1-\psi(c)$ is the mass of parents willing to pay for the conditionality. Finally, we assume that in our experimental setup, all governmental transfers sizes are larger than $\underline{T} \equiv \bar{Y}-Y$, so that the level of household income is always above the minimum level of transfers to the child that induces school attendance.

\section{The experiment}

\subsection{The setup}

We conducted the experiment with 210 families ${ }^{26}$ All of them were already enrolled and benefiting from the CCT program (Bolsa-Escola Vida Melhor) ${ }^{27}$ For each family, we interviewed one parent and one child between thirteen and fifteen years of age. Those families were all enrolled in the program and hence at the time were receiving $R \$ 120$ per month conditional on school attendance of that child to at least $85 \%$ of classes each month.

We focused on children between between thirteen and fifteen because these children may have already formed individual preferences, some bargaining power in the household and an outside option to schooling 28 This is also the age range at which school attendance drops considerably. According to the official Brazilian household survey (PNAD), by age sixteen, dropout rates reach $26 \%$ for children in Brazil with a household monthly per capita income less than $\mathrm{R} \$ 100$ (the average level of household monthly per capita income among beneficiaries of the Bolsa-Escola program was about R $\$ 65$ in 2009). Finally, these are also the oldest CCT-eligible students, since payments stop when the child turns sixteen.

Families invited to the experiment were randomly chosen among those enrolled in the Bolsa-Escola program. First, a district was randomly chosen within all of the school districts in Brasilia. Second, within each chosen

\footnotetext{
${ }^{26}$ This experiment would fall under "framed field" according to the nomenclature presented by Harrison and List (2004), and List (2008).

${ }^{27}$ The agreement with the local government was made possible with the help of the local NGO Missao Crianca.

${ }^{28}$ In the whole country, over $22 \%$ of fifteen year-old children from the bottom quartile households in the distribution of household per capita income reported to have a job during the week they were interviewed for the 2006 PNAD.
} 
district, a number of schools were randomly chosen. Finally, within each chosen school, a number of students were randomly chosen. We interviewed families from eleven schools in four of the existing twenty districts in the Distrito Federal state (for a discussion on the representativeness of our sample, see the Supplemental Appendix). We only included children who had no older CCT-eligible siblings to ensure that a family would only be invited once. Families were recruited with letters distributed to the child by their school's principal on Thursday or Friday, inviting them to attend a one-hour study at the child's school over the weekend. Families were offered either $\mathrm{R} \$ 7$ or $\mathrm{R} \$ 10$ to attend the study ${ }^{29}$ The average show-up rate in our study was $87 \%$ (see the Supplemental Appendix for details on show-up rates).

When participants arrived, each family was randomly assigned into one of the treatments described in the next four subsections. The randomization was based on the last two digits of the parent's Cadastro de Pessoa Fisica (akin to a Social Security Number in the United States). The parent was seated at a computer, and the student was asked to wait in a separate room. If there were no free computers, the parent would wait as well 30 One surveyor was assigned to each participant to read the survey questions ${ }^{31}$ Only clarifying questions asked by participants were answered by surveyors. All clarifying questions regarding the treatment questions were addressed by the author conducting the experiment. Surveyors were randomly ordered at the beginning of the day and assigned according to availability throughout the rest of the day. In every treatment, the parents would complete their portion of the experiment first. The children would go second, with the parents leaving the room. In some of the treatments (as described below), there was a joint decision-making portion, which followed the children's part.

In any treatment, the experiment began with the surveyor offering the parent the opportunity to choose a new cash transfer program. There were twenty-five questions, each one a choice between a cash transfer conditional on a behavioral outcome of their child (e.g., like their current CCT program) or an unconditional transfer, also paid monthly in the same manner, to the same parent. Each treatment varied the specifics of the conditionality or the informational features of the choices, but the structure and sequence of the questions was always the same. Each question varied the relative size of the conditional and the unconditional transfers. That is, subjects were offered series of binary choices - a CCT worth R X or a CT worth R \$ Y - and X and Y were varied for each choice.

The minimum amount was always $\mathrm{R} \$ 120$, ensuring the family could not leave with a transfer that paid less than their original one. First, the questions held constant the amount of the CCT at R\$ 120 and increased the

\footnotetext{
${ }^{29}$ See a sample invitation letter and its English version in the Supplemental Appendix.

${ }^{30}$ If there was a long wait, subjects would play BINGO for small prizes.

${ }^{31}$ Surveyors were all undergraduate students from the University of Brasilia.
} 
CT from $\mathrm{R} \$ 120$ to $\mathrm{R} \$ 180$ in increments of $\mathrm{R} \$ 5$, as presented below:

\begin{tabular}{cccc}
\hline \hline \multicolumn{3}{c}{ Which Monthly Payment } & Would Your Prefer? \\
\hline $\mathrm{R} \$ 120$ Conditional on Attendance & OR & $\mathrm{R} \$ 120$ Unconditionally \\
\hline $\mathrm{R} \$ 120$ Conditional on Attendance & OR & $\mathrm{R} \$ 125$ Unconditionally \\
\hline$\vdots$ & & \\
\hline $\mathrm{R} \$ 120$ Conditional on Attendance & OR & $\mathrm{R} \$ 180$ Unconditionally \\
\hline
\end{tabular}

Secondly, the questions held constant the amount of the CT at R\$120 and increased the CCT from R\$ 125 to $\mathrm{R} \$ 180$ in increments of $\mathrm{R} \$ 5$, as presented below: 32

\begin{tabular}{cccc}
\hline \hline \multicolumn{3}{c}{ Which Monthly Payment } & Would Your Prefer? \\
\hline $\mathrm{R} \$ 125$ Conditional on Attendance & OR & $\mathrm{R} \$ 120$ Unconditionally \\
\hline $\mathrm{R} \$ 130$ Conditional on Attendance & OR & $\mathrm{R} \$ 120$ Unconditionally \\
\hline$\vdots$ & & \\
\hline $\mathrm{R} \$ 180$ Conditional on Attendance & OR & $\mathrm{R} \$ 120$ Unconditionally \\
\hline
\end{tabular}

To minimize time spent on this procedure in these time-intensive surveys, as soon as a parent indicated a switch in preference from a conditional transfer to an unconditional transfer (or vice-versa), the research assistant would presume the parent similarly preferred all unconditional (or conditional) transfers worth more. Thus we induced monotonicity in the decisions. Decisions are not always monotonic (e.g., Holt Laury (2002), who use a modified Becker DeGroot Marschak procedure, find that 5.5\% and 6.6\% of their subjects revealed non-monotonic preferences in their high and low stakes risk preference elicitation treatments). If the parents would have otherwise submitted non-monotonic preferences, then the reported levels of willingness to pay for conditional transfers may be understated in our experiment (since we are only observing the first switch). However, the results section relies on cross-treatment analyses rather than emphasizing levels. Hence concern would only arise if non-monotonicities interacted with the treatment effects. We have no reason to suspect it would, especially to drive treatment effects the size of which we observe.

Each treatment used these same twenty-five conditional versus unconditional transfer questions 33 Parents were informed that $5 \%$ of participants would have one of their decisions implemented and that decision would

\footnotetext{
${ }^{32}$ It is possible this ordering may have an effect within one treatment, but assuming this does not interact with treatment effects, this will not affect the analysis across treatments.

${ }^{33}$ See the actual set of twenty-five questions and text in Portuguese used in each treatment and their translated versions in English in the Supplemental Appendix.
} 
be randomly chosen from the 25 questions ${ }^{34}$ Any change would last through the end of the current school year, for four months (from September to December 2009) and would only apply to the child present at the experiment.

All sessions were performed between June and July 2009 35 The experiment was conducted at computer terminals using a web-based survey ${ }^{36}$ Subjects were not allowed to interact with each other in the computer lab. No communication within or across families was allowed during the entire experiment ${ }^{37}$ For each family, total participation took no longer than one hour.

\subsection{Experimental treatments}

Table 1 reports the description and comparison of all treatments.

\subsubsection{Baseline treatment}

The sixty families in this group made the sequence of choices just described in which the conditional transfers have exactly the same conditionality as in the Bolsa-Escola program: class attendance on $85 \%$ of the days every month ${ }^{38}{ }^{39}$ The choices were offered first to the parent, then the child, then jointly, but were only financially incentivized for the parents 40 The parent was informed that the child would be informed of the choices made by the parent at the very end of the session. This treatment enables us to estimate the mass of parents willing to pay for the conditionality, $1-\psi(c)$. Finally, as we describe next, when combined with the findings of the next treatment (the Don't Tell treatment), the Baseline treatment will also let us check our assumptions of diverging

\footnotetext{
${ }^{34}$ Hence, this is a version of the Becker DeGroot Marschak elicitation procedure, which incentivizes truthful reporting of willingness to pay.

${ }^{35}$ We performed an experimental pilot with thirty-five families in March-April 2009 mostly focused on surveying the families, with no treatments. A discussion on the pilot experiment design and results can be found in the Supplemental Appendix. Two additional experimental treatments designed to further analyze what drives parental valuation of schooling were performed over the telephone after the implementation of the main experiment, in September. The description and results from these treatments are reported in the working paper version of this paper.

${ }^{36}$ In all but one school, CEF 20 Ceilandia, the experiment was performed using Qualtrics' web-based survey platform. In that school, since the internet connection was slow during the intervention, an identical (content-wise), though visually different, pdf computer survey was used. Although a pdf-survey fixed effect cannot be disentangled from the school fixed effect, the data from this school and survey are very similar to the data collected in the other schools. The final results do not change if the data from that school are excluded, so they are not. The results excluding that school are available in the Supplemental Appendix.

${ }^{37}$ Since all the relevant decisions and outcome variables were made and measured during the experiment, we are not concerned about communication outside of the experimental sessions.

${ }^{38}$ See the entire questionnaire used in the Baseline treatment and its English version in the Supplemental Appendix.

${ }^{39}$ Earlier versions of this paper reported one or two more subjects in three of the treatments, including the Baseline. 214 surveys were pulled up on computers, but four were never initiated; hence here we will report 210 parents. 208 families completed the survey (two left before the children started), hence some data analysis will necessarily report two fewer data points.

${ }^{40}$ The analysis of the child's and joint decisions can be found in the Supplemental Appendix.
} 
schooling preferences across generations in the analyzed households.

\subsubsection{Do parents need a device to control the child? Don't Tell treatment}

This treatment, combined with the findings from the Baseline treatment, serves to verify our assumptions that there exists a divergence in preferences in the studied households (with parents on average positively valuing their child's school attendance, $\hat{V}>0$, and the child facing a positive cost of school attendance, $c>0$ ). The treatment, assigned to forty-seven families, is identical to the baseline except the CCT-CT question for the parents was preceded by a short disclaimer saying that we would not tell the child if their transfer program was changed, and that the child would not be offered a CCT-CT decision. ${ }^{41}$ Thus, the children would not have any reason to believe the family would be leaving with anything other than the CCT program with which they came. As a result, if parents want the CCT as a device to induce the child to attend school, then even those parents with $V>c$ (who would be willing to pay for the conditionality if offered the set of choices from the Baseline treatment) could now choose the larger of the two transfers and allow the child to believe the transfers are still conditional on attendance 42

\subsubsection{Monitoring and parental control: Text message treatment}

If monitoring is a problem in the household, then providing the parent with a level of monitoring $\pi$ comparable to the one provided by the CCT should decrease the need to pay to keep the conditionality on the payments. It follows from Proposition 2 that the fraction of parents willing to pay for the conditionality should go to zero, unless some parents believe the CCT still provides more monitoring.

This treatment, assigned to fifty-one families, is identical to the baseline except the CCT-CT question for the parents was preceded by offering the option of receiving a free text message sent to their cell phone every day their child misses class. Parents were greeted with a screen offering them the free service and asking them for their cell phone number if they would like to sign up 43 The rest of the experiment proceeded identically to

\footnotetext{
${ }^{41}$ In this treatment, the child would only answer questions about demographics, preference parameters, etc.

${ }^{42}$ This treatment there provides evidence that the demand for the conditionality is mainly driven by a parent-child conflict about school attendance, thus helping us rule out other competing explanations. Three of those competing explanations are: (i) a parent facing an immediate cost of inducing school attendance and only earning benefits in the future could demand the conditionality as commitment device to solve a self-control problem and make sure the child attends school; (ii) a parent could demand the conditionality to control the behavior of a spouse who would otherwise prevent school attendance by the child; (iii) a parent that is unable to commit to an ex-ante optimal punishment strategy to a child that misses school could demand the conditionality because it decreases household consumption if the child misses school and can thus be seen as a commitment device to punishing the child.

${ }^{43}$ Only two parents in this treatment did not have a cell phone. The other forty-nine accepted the offer. All fifty-one are included in the analysis.
} 
the baseline. In summary, combined with the Baseline treatment, the Text message treatment lets us test the implications of Proposition 2 in terms of parental observability of the child's attendance behavior $(\pi)$.

\subsubsection{School as a bunker: the Non-classroom treatment}

We also use the same experimental setup to attempt to understand what drives parental demand for schooling for their children. This treatment addresses parental valuation of the non-classroom content of school, such as keeping the child off the streets ${ }_{44}^{4 n}$ violent urban areas like the one we study, keeping the child safe and off the streets might be valued by the parents. For example, in one superquadra (akin to a city block) where one of the schools is located, in the city of Ceilandia, five homicides were reported in 2008 alone (according to data from DF Secretariat of Public Safety) 45

Children only attend a half-day of classes at public schools in Brasilia, either in the morning (from eight to twelve) or the afternoon (from two to six) ${ }_{46}^{46}$ They are welcome (but not required) to be at school during the other half of the day, but they do not have any classes. In this treatment, to which fifty-two families were randomly assigned, parents were asked to choose between a cash transfer conditional on their child's attendance at school in the half of the day they are not in class (still at 85\%) and unconditional payments. These choices are binary decisions, identical in sequence and monetary value to those in the other treatments. For these decisions, the parents were told there was no conditionality regarding attending classes. This means that if the child misses every day of class, the parent will still be paid the transfer so long as the child attends the other half of the day. There are no requirements regarding the activities performed in school during the no-class shift. There are no classes being offered and the child can do whatever he or she wants (except attending classes), as long as it occurs inside the school limits. Schools in the areas we study are generally protected by tall concrete walls and sometimes barbed-wire fences ${ }^{47}$ The child's attendance during the no-class shift is monitored by a school guard. The child is still welcome to attend class during the usual class shift.

Children in this treatment group were informed about the choices made by their parents. To make sure parents

\footnotetext{
${ }^{44} \mathrm{Katz}$ et al (2001) report that $53 \%$ of disadvantaged parents who applied for housing vouchers did so to "get away from drugs and gangs" while only $18 \%$ were driven by the opportunity for "better schools for [their] children." Kling et al (2005) further show that the child's neighborhood may be a good predictor of whether the child is involved in crime. Goldin and Katz (2008) provide historical evidence that child labor laws generally exempted older youths, constrained by the compulsory schooling law, conditional on going to work.

${ }^{45}$ Pregnancy rates among teenagers are also quite high in the areas that we study. According to the Brazilian Ministry of Health, in 2004, 15.8\% of all live births in the entire DF state (including both poor and rich areas) were from mothers aged fourteen to nineteen.

${ }^{46}$ In a reduced set of public schools, children at the age range we study may attend school during an evening shift instead. In our sample, two children attend school during that shift. However, for both cases, the parent is not in the Non-Classroom treatment group (one parent is in the Text message group, and the other, in the Don't Tell group).

${ }^{47}$ See pictures of some of the schools in the Supplemental Appendix.
} 
did not leave with a less preferred cash transfer program than their current program, they were later asked to choose between their current program-a CCT of R 120 conditional on attendance during the classroom shift—and the alternative they had just chosen. They were not informed that they would be offered that option while they were making their initial choices in this treatment.

\subsection{Experimental Outcomes and Empirical Specification}

We are interested in parents' choices between CT's and different types of CCT's. Consequently, we focus on three outcome variables:

1. A dummy variable that is equal to one if the parent prefers a R \$ $120 \mathrm{CCT}$ to a R\$120 CT (the parent is demanding the conditionality), and zero otherwise.

2. A dummy variable that is equal to one if the parent prefers a $\mathrm{R} \$ 120 \mathrm{CCT}$ to a $\mathrm{CT}$ that pays strictly more (the parent is paying for the conditionality), and zero otherwise.

3. The level of CT payment that makes the parent indifferent to a R\$120 CCT (the parent's threshold).

To estimate the effects of the treatments described previously, we make mean or median comparisons of these three outcome variables across treatments. Although the assignment to treatments was random, we estimate treatment effects controlling for observables. To that end, we use each one of these three measures separately as our dependent variables and run the following OLS regression in our empirical analysis:

$$
Y_{i}=\alpha+v X_{i}+\phi_{1} I_{\text {Don't tell }, i}+\phi_{2} I_{\text {Text message }, i}+\phi_{3} I_{\text {Non-classroom }, i}+e_{i},
$$

where $Y$ is one of the three measures mentioned above, $X$ is a vector of controls, and $I_{j}$ are the dummies for whether the parent received a treatment other than the Baseline treatment: the Don't Tell treatment, the Text message treatment, and the Non-classroom treatment. Therefore, the treatment dummies measure the effect of each treatment compared to the baseline.

In our main specifications, we include the following covariates: treatment dummies, marital status (parent), log of household income, male indicator (parent and child), age (parent and child), employed parent indicator, employed parent's spouse indicator, religion dummies, schooling (parent and child), number of children in the household, dummy on whether the household has been receiving CCTs for more than one child, beta [a measure 
of time inconsistency discount factor] (for the parent and her child), delta [weekly discount factor] (parent and child) 48 , race dummies (parent and child), dummy for higher show-up fee, school and surveyor dummies, with the standard errors clustered by school in our baseline specification 4950

\section{Treatment Results}

\subsection{Summary statistics and motivating evidence}

Table 2 presents summary statistics for our variables of interest across treatment groups. With very few exceptions, the means are not significantly different from the baseline group. This suggests that the randomization was successful.

To motivate our analysis of the parent-child conflict, Table 3 presents the means and medians of parents' and children's perceptions of current monthly wages the children could earn if they decided to drop out and work instead, and the monthly wage premia from additional years of schooling (and the average yearly returns to schooling). Regarding beliefs of wage premia and returns to schooling, the means between parents and children seem similar (and are insignificantly different), due to two children reporting very high expectations 51 The medians however are highly significantly different. We only have measures of the perceived returns to schooling, however. We do not have measures of the perceived cost of schooling for parents and children. Since the child is the agent actually going to school, it seems plausible that the child might have a higher private cost of attending school. This would exacerbate the divergence in preferences within each household. Unfortunately, we cannot address this concern.

We also present in Table 3, the means and medians of both parents and children's beliefs about the average monthly wage of someone with a high-school or college degrees, together with the actual empirically observed average in Brazil (using the data from PNAD 2007 and updating the values using the Brazilian consumer price index for 2007 and 2008). As we can observe, the parents surveyed are not misestimating the actual wage levels

\footnotetext{
${ }^{48}$ For a discussion on the construction and measure of time preference parameters, see the Supplemental Appendix.

${ }^{49}$ For robustness, we also reproduced the regressions clustering the standard errors by surveyor and with Probit regressions when the dependent variable was binary. The results are available in the Supplemental Appendix.

${ }^{50}$ One of the research assistants, who was the hostess for the families that came to the study, would input her name as the surveyor as she sat down some families. However, she only conducted two interviews. For the purposes of our analysis, we consider the research assistant doing the interview to be the surveyor.

${ }^{51}$ If we exclude a few outliers (one child reported $\mathrm{R} \$ 180,000$ as the monthly wage increase from having a college degree) for most measures of returns to schooling, the difference is again significant for the means.
} 
in Brazil 52

Finally, we find evidence that parents are underinformed of their child's school attendance behavior. Only $5.6 \%$ of the children in the sample report that they commute to school with the company of their parents. In many families, parents have to leave home very early in order to be in downtown Brasilia in the morning, to either work or look for a job. Table 4 reports the parent's and the child's answers to questions regarding school attendance by the child. First, parents report on average lower school absences by the child than their child does. Also, parents are more likely to cite sickness as a reason for absence while the children are much more likely to report that "they missed class because they did not want to go.' 53

\subsection{Treatment effects}

In Table 5, we present average treatment effects without controls, by comparing the means and quartiles of our outcome variables across treatment groups. As explained before, we define a parent's "threshold" as the minimum amount of unconditional transfer that makes the parent indifferent to a conditional cash transfer of $\mathrm{R} \$ 120$. Since the questionnaires only offered the option up to $\mathrm{R} \$ 180$ in either direction (increasing the CCT or the CT), our measure of the threshold is censored ${ }_{54}^{54}$ As a result, we also report the value of parents' threshold evaluated at the first quartile, median and third quartile of the threshold distribution for each treatment group.

Table 6 presents the results from regressions of our main outcome variables on the set of covariates described in the previous sections $\sqrt[55]{5}$ Due to the censoring problem, we use two threshold measures: one based on the original, censored data (henceforth parents' "Censored threshold") and another based on data extrapolated using a Tobit regression of parents' threshold on the set of covariates of our baseline specification (presented before), henceforth their "Extrapolated threshold.' ${ }^{56}$ To further deal with the censoring issue, we also present the results from quartile regressions. As expected, the estimates of the treatment effects controlling for observables are very similar to the treatment effects derived from the comparison of means across treatment groups without controlling for observables.

\footnotetext{
${ }^{52} \mathrm{We}$ found no significant differences in time-preference parameters between parents and children. This is consistent with experimental results by Bettinger and Slonim (2007) that show that by the age of sixteen, discount rates are fairly similar between parents and their children.

${ }^{53}$ We should not forget that all these children were receiving a conditional cash transfer at the time of the experiments, which could set a bound on the number of classes they could miss.

${ }^{54}$ For $34 \%$ of the respondents, a $\mathrm{R} \$ 120 \mathrm{CCT}$ was still preferred to a $\mathrm{R} \$ 180 \mathrm{CT}$. On the other direction, for $12 \%$ of the respondents, a R\$ 120 CT was still preferred to a R\$ 180 CCT.

${ }^{55}$ Two subjects are dropped from the regressions because they did not answer all of the control variable questions.

${ }^{56}$ Details relating to the construction of these thresholds are found in the Supplemental Appendix.
} 


\subsubsection{Baseline treatment}

Within that group, $88.5 \%$ of the parents choose a conditional transfer over an unconditional transfer of equal or greater amount (they "demand" the conditionality) while $82 \%$ prefer at least one conditional transfer that paid strictly less than an unconditional transfer (they "pay" for the conditionality).

The parent's average censored threshold in this treatment group is $\mathrm{R} \$ 157.3$. This is a lower bound of the true average due to censoring (63.3\% of the parents in the Baseline treatment group prefer a CCT of R $\$ 120$ to a CT of $\mathrm{R} \$ 180$ ). That is, parents, on average, are willing to forego at least $\mathrm{R} \$ 37.3$ to keep the conditionality. This is over six percent of their pre-CCT level of household monthly income. The mean level of the extrapolated threshold in this group is $\mathrm{R} \$ 200.9$. Due to the censoring problem, we look at quartiles in the distribution of the censored thresholds: the first quartile is at $\mathrm{R} \$ 127.5$ and the median is already $\mathrm{R} \$ 180$. We plot the cumulative distribution for the censored threshold in the Baseline treatment group in Figure 1

In Table 6, we observe that the show-up fee does not significantly affect the demand for conditionality or the size of the threshold. As the show-up rate to the experiment was already very high for the lower show-up fee (show-up rate of $85 \%$ ), selection does not seem to be driving our findings ${ }^{57}$ There could also be a concern that social desirability and/or experimenter demand effects may be driving the results. We address these issues in subsection 5.2.6. We also control for a dummy variable on whether the family has been paid CCTs for more than one child. In our specifications, the effect of this variables is never significant, either statistically or economically. Whether the parent is employed or not and whether the parent's spouse is employed or not do not seem to affect significantly preference for the conditionality either. This might suggest when children do not attend schooling, they do not spend the day at home. This is consistent with the interpretation of results for the Non-classroom treatment 58

\subsubsection{Conditional cash transfers to control the child: Don't Tell treatment}

Using this treatment, we check the validity of the assumptions of our model. If the demand for the conditionality is driven by a parent-child conflict and thus by the parent demanding a device to induce school attendance, then if the child believes that the conditionality still holds (and is is therefore incentivized to attend school), the parent should be less willing to pay to keep the conditionality. Both in the comparisons of means and the

\footnotetext{
${ }^{57}$ See the Supplemental Appendix for a discussion on the show-up rates of our study.

${ }^{58}$ In our specifications, we do not control for beliefs of returns to schooling since we do not observe parents' perceptions of the child's private cost of going to school, which combined with the parent's perception of the child's beliefs of returns to schooling (that we also do not observe) would generate our variable of interest.
} 
regression results, we observe a substantial drop in the preference for conditionality when compared to the Baseline treatment.

The treatment effects in Table 6 indicate that a large portion of the preference for the CCT is therefore explained by the need to control the child. The probability of demanding the conditionality goes down from 0.88 to 0.44 and the probability of paying for the conditionality drops from 0.82 to 0.25 , compared to the Baseline treatment. Furthermore, the extrapolated threshold is reduced by $\mathrm{R} \$ 55.9$ (the censored measure drops by $\mathrm{R} \$ 30.1$ ). For all but one of those four outcome variables, the treatment coefficients are significant at $1 \%$ (the p-value for the coefficient is 0.013 when the outcome variable is the censored threshold). In columns 5-7 of Table 6, we present the results from quartile regressions of the censored threshold. As expected, for parents with low levels of willingness to pay for the conditionality in the Baseline group (censored thresholds equal or lower than R\$125), the Don't Tell treatment would have a smaller effect (since the parents did not need the CCT device to start with). However, for parents with higher willingness to pay for the conditionality, the Don't Tell treatment has a stronger effect, similarly to the mean regressions presented before. Finally, Figure 2 illustrates the treatment effect by plotting the cumulative distribution for the censored threshold in both the Baseline and Don't Tell treatment groups 5

Jointly, the results from the Baseline and Don't Tell groups provide evidence that in our setting, on average: (i) parents and children have different preferences regarding schooling; (ii) parents positively value their child going to school $(\hat{V}>0)$; (iii) children face a positive net cost of attending school $(c>0)$. We need all these three conditions in order for most parents, all else equal, to be willing to pay to keep the conditionality, and most of them not paying for it anymore when their child believes that the conditionality is still binding.

Finally, it is worth noting that a possible source of concern regarding the overwhelming preference for conditionality in the Baseline treatment could be the presence of some parental preference for maintaining the status quo. Parents were all enrolled in the local CCT program and could be hesitant to drop the current payment scheme and choose another one instead. However, the fact that the vast majority of parents are willing to drop their current payment scheme when the child is not informed of their choice suggests that explanation does not seem to be driving the preference for conditionality.

\footnotetext{
${ }^{59}$ The residual preference for conditionality after the Don't Tell treatment is imposed could be explained by the inability of the parents to hide information from the child and by other reasons that are addressed in the Supplemental Appendix.
} 


\subsubsection{Monitoring and parental control: Text message treatment}

This treatment is designed to address the implications of Proposition 2 of our model in terms of parental ability to observe the child's actions. Our previous results suggest that the vast majority of the parents in our study might not be able to enforce school attendance by themselves and are willing to pay for an external device (the conditionality on the payments) for that purpose. If the need for that external device is mainly driven by parents' inability to monitor their children, providing near-perfect information to parents on their children's attendance behavior if they choose an unconditional cash transfer (i.e., shifting $\pi_{C T}$ close to one), should reduce significantly the preference for conditionality.

Both in the comparison of means and in the regression analysis, we observe a substantial decrease in parental preference for conditionality, when compared to the Baseline treatment. The treatment effects in Table 6 attest that observability is an important problem and that an increase in the degree of information parents have about their child's school attendance drastically reduces the necessity for the conditional cash transfer as a monitoring device. When offered another free monitoring device (text messages), most parents do not need to spend money to keep the conditionality on their cash transfers. The probability of demanding the conditionality is reduced from 0.88 to 0.35 , and the likelihood of paying for the conditionality drops from 0.82 to 0.29 when compared to the Baseline treatment. Also, the extrapolated threshold drops by $\mathrm{R} \$ 54.6$ (the censored measure decreases by $\mathrm{R} \$ 31.5)$. For all those four outcome variables, the treatment coefficients are significant at $1 \%$. Columns 5 to 7 present the treatment effects from quartile regressions of the censored threshold variable. There again, the treatment effects are comparable to the mean effects, with the exception of the first quartile (where parents would not demand conditional payments anyway). Figure 3 illustrates the treatment effect by plotting the cumulative distribution for the censored threshold in both the Baseline and Text message treatment groups.

These results indicate that a significant portion of the preference for conditionality is due to the higher monitoring level of the child's action offered by the CCT. When it is no longer higher, preference for conditionality is considerably reduced ${ }^{60}$ However, some parents still pay for the conditionality when they are endowed with better information (text messages). We do not address experimentally the exact motive behind that residual preference 61

\footnotetext{
${ }^{60}$ These findings also reduce the concern that the preference for conditionality in the Baseline treatment was driven by a parental fear of being stigmatized as benefiting from a pure welfare program that hands out cash. According to that view, parents could demand the conditionality because they believe that they are providing something instead; they have co-responsibilities in a CCT program. However, the fact that most parents are willing to drop the conditionality in the Text message treatment suggests that the fear of a stigma associated with receiving unconditional cash transfers could not be driving the preference for conditionality.

${ }^{61}$ Three possible groups of reasons for those parents are: (i) the parent does not think that text messages imply better monitoring than the CCT: the parent might not be willing to move away from a mechanism that is certain to work (CCT); the parent might think she
} 
The findings above therefore suggest that parents are willing to pay substantial sums of money for monitoring devices informing them about their child's attendance behavior. It is important to notice that under the status quo, parents have been receiving conditional cash transfers from the local government since 1995. Parents are therefore requiring high sums of money to drop the conditionality. The conditionality could be thought of as an equilibrium outcome for parents' demand for more control over their child's behavior. Finally, in our study, parents were asked to report their choices privately and in the lab, without knowing who else was going to be offered to make the same choices. This could also help explain why many of them are willing to pay such large amounts for monitoring devices, since those parents were not able to coordinate and maybe develop an alternative, private solution to their common monitoring problem.

\subsubsection{Schools as bunkers? - Non-classroom treatment}

Table 6 shows that the Non-classroom treatment reduces preference for conditionality when compared to the Baseline treatment group, but the demand for conditionality is not eliminated. When compared to the Baseline group, the treatment reduces the likelihood of paying for the conditionality from 0.88 to 0.74 (not statistically significant) and the probability of paying for the conditionality from 0.82 to 0.68 (not statistically significant). The treatment decreases the threshold measured by the extrapolated data by $\mathrm{R} \$ 34.3$ (significant at $1 \%$ ) and the censored threshold by $\mathrm{R} \$ 16.3$ (significant at 5\%). Columns 5-7 present consistent results from quartile regressions of the censored threshold variable. Figure 4 illustrates the treatment effect by plotting the cumulative distribution for the censored threshold in both the Baseline and Non-classroom treatment groups. This suggests that a non-negligible portion of parental desire to control their child is to make sure the child attends school, and not necessarily classes 62 63

could lose her cell phone, change her number or have an income shock that forces her to sell the device for instance; (ii) the parent needs the conditionality to control someone other than the child: the parent might want the CCT to prevent someone else from not letting the child attend school or to commit herself to let the child attend school. Only one of the nine parents that still pay for the conditionality in the Text message treatment group has time-inconsistent preferences. Therefore, we believe that the remaining preference is not a problem of parental self-control (for more discussion on the role of time-inconsistent preferences, see the Supplemental Appendix); (iii) the child cares about household income: if the chid is altruistic toward the parent's consumption level or if the parent spends a share of her consumption on a household public good also enjoyed by the child, then the CCT provides an additional incentive for the child to attend school, which a CT with perfect monitoring would not provide.

${ }^{62}$ After choosing their payment schemes, parents were asked whether they would prefer to revert back to their current CCT program or if they would rather abandon it and take the one based on attendance during the shift in which the child has no classes; $42.3 \%$ of the parents reported they would prefer to be part of the new program.

${ }^{63}$ One could ask why after-hour school programs are not being provided in the DF state if there is high demand for such type of program. We offer two potential explanations. First, from the perspective of a public provision of this type of program, there may not be enough space for all students to stay in school during the whole day (a reason for the existence of two class shifts). Second, from the private provision standpoint, a solution would face two great obstacles: i) the children will not necessarily be willing to go to the after-hours program and our analysis suggests a current lack of parental control over their children's behavior; (ii) to keep children safe, schools are surrounded by tall concrete walls and sometimes barbed-wire fences; safety is not a cheap or easy thing to ensure. One 


\subsubsection{Heterogeneity of treatment effects according to parents' perception of observability of the child's}

\section{behavior}

Our treatment effects suggest an informational story: parents in our study highly value monitoring devices that could help them control their child's behavior. To address the robustness of our findings and test our predictions in more depth, we study how parents' perception of their ability to observe their child's behavior affect our treatment effects.

\section{- Text message treatment and perception of observability}

For parents that believe they already had a high level of information about their children, we would expect a weaker treatment effect (the increase in observability of the child's action from the treatment is lower). We test this by interacting the Text message treatment dummy with a measure of how much the parent already observes her child's actions regarding school attendance. In the study, parents were asked to estimate in a scale from 0 to 5 how much they think they know about what her child is doing during her day. Table 7 shows the results of the interaction of the Text message treatment dummy with this measure of (beliefs about) observability, where we use a standardized measure (zero mean and unit variance) of the 0 to 5-scale variable 64 The results are merely suggestive, but they seem to indicate that for parents who report better abilities to monitor their child, the Text message treatment has a weaker effect.

\section{- Non-classroom treatment and perception of observability}

We would like to check whether the parent is keeping the conditionality when offered the new program in order to control a child that is more likely to be on the streets when not in class. We do not have an exact measure of how much parents think their child is likely to be on the streets, but we can use our measure of how much the parent believes she knows about what the child is doing during her day. The interaction effects are reported in Table 8

The results indicate that the demand for a device to make the child be in school when the child does not have classes is much higher when parents do not know what their children are doing during their day. The

final note is that attempts have been made to provide safety in the form of extended school days. The principal from one the schools in the DF state, Carlos Mota, was murdered on June 20, 2008, while attempting to implement extended school hours; he was believed to be shot for creating obstacles for the drug-selling business in the areas surrounding the school. Source: Santos. F., Reis, M. (2008) "Diretor de escola é assassinado," DF TV $2^{a}$ Edicao, June 20.

${ }^{64}$ With the standardized measure, the coefficient on the treatment dummy indicates the effect evaluated at the mean level of the scale variable, and the coefficient on the interaction term indicates the change in the treatment effect when moving that variable by one standard deviation. 
interaction term is significant in all four specifications. More interestingly, the results point that, for parents that knew what their children are doing one standard deviation less than the mean of that variable, the preference for conditionality and the level of the threshold would be almost identical to the ones in the Baseline treatment, but now under this new CCT program that only requires attendance when the child is not in class.

\subsubsection{Experimenter demand effects and social desirability}

Although the respondents are choosing payment schemes under real stakes, they might be tempted to choose what they feel to be socially or experimenter-approved decisions. We can shed light on these ubiquitous experimental concerns in a few ways. First, we had seventeen surveyors with varying levels of experience and knowledge. Some helped with only a few parents while some did as many as thirty-eight. Some came to our training session while others (unfortunately) had minimal training. While we never told any surveyor the hypotheses of the experiment, one could reasonably assume that with more experience and training, they could more readily infer the goal of the study. If we consider experience or training as measures of surveyor knowledge, and hence the "double-blindedness" of an interview, we can address these issues. If we linearly interact the treatment dummies with an indicator of whether the surveyor received training and include these in the main regression specifications used before, as presented in Table 9, we observe that training never significantly affects the treatment effects, and the direction of the interaction is generally towards attenuating our main findings. We also compute a measure of surveyor experience, by calculating, for each experiment session, the number of interviews that each surveyor had conducted before that session. In Table 10, we report the interaction analysis of the treatment effects with our measure of surveyor experience. We observe that experience, also, if anything, seems to attenuate the treatment effects.

Although it is not immediately clear in which direction social desirability should be pushing the willingness

to pay in each treatment-Should "good parents" declare they have no child control problems or rather be willing to pay for an external control device?-it is always a legitimate concern in experiments, especially involving face-to-face interactions. It is difficult to directly measure social desirability, but there seems to be little evidence indicating that it is driving the results. First, the parents are, on average, 40 years-old, and the surveyors are all college-aged. Second, the stakes are real and potentially large. Third, most subjects report stigmatized behaviors and beliefs, such as the fact that they would be willing to lie to their child (or hide something from the child), an implicit result from the Don't Tell treatment. Also, the interaction terms in some of the regressions presented before are informative. If the results were highly affected by social 
desirability effects, we would not expect the treatment effects to vary according to variables such as perceptions of observability of the child's action by the parent.

\section{Concluding remarks}

Using a real-stakes experiment, we study the schooling decisions of poor households with adolescent children in urban Brazil. We provide evidence that the following aspects, treated as secondary in the standard economic approach to schooling, can play a crucial role in the actual decision-making process:

First, in the setting we study, intergenerational conflict is central to the schooling decision. There is a divergence in preferences across generations within each household: parents highly value their children being in school and do so more than the children themselves do.

Second, we observe that informational asymmetries can play a crucial role: parents reveal an inability to observe the actions of their children and are willing to pay substantial sums for mechanisms that can increase their monitoring and control over their children's school attendance.

Third, we show that in the slums that we study, parents seem to substantially value schooling even if the child is not in the classroom, and thus learning. Skills acquisition, traditionally viewed as the quintessential role of schooling, does not seem to comprise wholly parents' demand for schooling.

These results depart from the usual approach to schooling in economics, where family conflict and agency issues play, at most, a secondary role, and where schooling is viewed primarily as a means of skills acquisition. Taken together, our results suggest that parents in poor households may not be able to control their child's decisions on schooling investment and safety. The consequence may be low investment in education and overexposure to violence, both being consistent with unfortunate current trends in the geographical area we study, with the population we study.

These findings can have important implications in terms of policy design, particularly in developing countries. The puzzle of low levels of school attainment in countries such as Brazil, where returns to schooling are high and where there is no evident shortage of schools, is usually understood according to the standard approach (in which parents are assumed to make the decision for their children and where intrahousehold information asymmetries are absent) as evidence that parents either underestimate the actual returns, or that they cannot afford to have a child not working 65 In our sample, parents have accurate beliefs about the actual returns to

\footnotetext{
${ }^{65}$ Edmonds (2006) and Edmonds and Schady (2009) provide evidence that increasing household income through transfers reduce
} 
schooling. Also, for the average family in the study, income does not seem to be a constraint that forces parents to prefer an unconditional payment: preference for the conditionality persists even for the poorest households in our sample 66

This paper provides evidence in favor of a different explanation to the aforementioned puzzle, based on informational issues inside the household: parents want their children to go to school but cannot directly enforce their desire. According to this approach, policies designed to promote school attendance might be more effective if they target the child or the household information structure instead of focusing on parents, as many of them do in practice. If parents in our study are correct in their beliefs, all that is necessary for many of them to promote school attendance is to provide them with more information (and therefore increased control) regarding their children's actions. If the goal of policy is to ensure school attendance alone, with no concerns for redistribution, then sending text messages could be more cost-effective than conditional cash transfers.

On the other hand, we also provide prima facie evidence that conditional cash transfers (CCTs) can be a preferred alternative to unconditional cash transfers (CTs). It has been argued that CT programs may be superior to the current global trend of CCTs, since families know better how to optimize for their household, and that with a sufficiently large CT, families will be free to invest optimally in education. In the context of schooling that we study, recipients of these transfers surprisingly prefer the CCT as the conditionality provides a solution to their intrahousehold, intergenerational contracting problem. This gives a new rationale for adopting this type of program. In an environment in which providing parents direct information about their children's attendance is not available or feasible, CCTs that provide frequent monitoring by parents may be able to induce school attendance by the child, even when the parent is not able to enforce it by herself.

Additionally, in the context we analyze, we observe a strong demand for policies that could increase the safety provided to children. After-school programs, even without skills acquisition components tied to them, could have a significant impact on welfare. Local governments in Brazil (including the Distrito Federal government) have recently been implementing longer shifts with extra-curricular activities in public schools that are not space-constrained. Finally, the relatively low importance attributed to the classroom content of schooling might also suggest that there is room for a great deal of improvement in the educational quality of Brazilian public schools, or perhaps how the quality is viewed by the populace.

We end with directions of future research. It would be interesting to see how our findings would apply the allocation of children to labor and increase school attendance.

${ }^{66}$ Our regression results suggest that poorer parents are willing to pay less for the conditionality. This is consistent with the results in Bursztyn (2010) which show that poorer voters in Brazil are less likely to favor public educational spending relative to increases in cash transfers. 
to younger children: there is significant evidence that skills acquisition is most important in the early years of childhood, and that these skills work as a complement to those gained during adolescence (Cunha and Heckman, 2007). Also, parents most likely have more control over younger children. Another line of important future research would be to address the extent to which our findings concerning the key role of intergenerational conflict and agency problems in schooling decisions are central to schooling choices in other contexts, in particular in poor, rural areas, where the nature of the intrahousehold problem might be different from the one addressed in this paper.

\section{References}

Acemoglu, D., Angrist, J. (2000) "How Large Are Human Capital Externalities Evidence? Evidence from Compulsory Schooling Laws," NBER Macro Annual, No. 15, The University of Chicago Press, Chicago, IL.

Aghion, P., Howitt, P. (2009) The Economics of Growth, MIT Press Cambridge, MA.

Angelucci, M., De Giorgi, G. (2009) "Indirect Effects of an Aid Program: How do Cash Transfers Affect Non-Eligibles' Consumption?," American Economic Review, 99(1), 486-508.

Angelucci, M., De Giorgi, G., Rangel, M., Rasul, I. (forthcoming) "Family Networks and School Enrollment: Evidence from a Randomized Social Experiment," Journal of Public Economics.

Angrist, J., Bettinger, E., Kremer, M. (2006) "Long-Term Educational Consequences of Secondary School Vouchers: Evidence from Administrative Records in Colombia," American Economic Review, 96(3),847862.

Angrist, J., Krueger, A. B. (1991) "Does Compulsory School Attendance Affect Schooling and Earnings?," Quarterly Journal of Economics, 106(4), 979-1014.

Angrist, J., Lavy, V. (2009) "The Effects of High Stakes High School Achievement Awards: Evidence from a Randomized Trial," American Economic Review, 99(4), 1384-1414.

Ashraf, N. (2009) "Spousal Control and Intra-Household Decision Making: An Experimental Study in the Philippines," American Economic Review, 99(4), 1245-1277.

Attanasio, O., Kaufmann, K. (2009) "Educational Choices, Subjective Expectations, and Credit Constraints," NBER Working Paper 15087.

Baird, S., Chirwa, E, McIntosh, C., Ozler, B. (2009) "The Short-Term Impacts of a Schooling Conditional Cash Transfer Program on the Sexual Behavior of Young Women," World Bank Policy Research Working Paper 5089 .

Baird, S., McIntosh, C., Ozler, B. (2009) “Designing Cost-Effective Cash Transfer Programs to Boost Schooling among Young Women in Sub-Saharan Africa,” World Bank Policy Research Working Paper 5090.

Baland, J. M., Robinson, J. A. (2000) "Is Child Labor Inefficient?," Journal of Political Economy, 108(4), 663-679. 
Barrera-Osorio, F., Bertrand, M., Linden, L., Perez-Calle, F. (2008) "Conditional cash transfers in education: Design features, peer and sibling effects: Evidence from a randomized experiment in Colombia," NBER Working Paper 13890.

Barro, R.J. (1974) “Are government bonds net wealth?,” Journal of Political Economy, 82 (6), 1095-1117.

Basu, K., Van. P. H. (1997) “The Economics of Child Labor,” American Economic Review 88(3): 412-427.

Basu, K.,Tzannatos, Z. (2006) “The Global Child Labor Problem: What Do We Know and What Can We Do?," World Bank Economic Review, 17(2): 147-173.

Becker, G. S. (1964) Human capital: a theoretical and empirical analysis, with special reference to education, Columbia University Press.

Becker, G. (1974) “A theory of social interactions,” Journal of Political Economy, 82(6), 1063-1093.

Becker, G. S. (1981) A Treatise on the Family, Harvard University Press, Cambridge, MA.

Bergstrom, T. (1989) "A fresh look at the rotten kid theorem-and other household mysteries," Journal of Political Economy, 97(5), 1138-1159.

Bernheim, B,D., Shleifer, A., Summers, L. (1985) “The Strategic Bequest Motive," Journal of Political Economy, 93(6), 1045-1076.

Berry, J. (2009) "Child Control in Education Decisions: An Evaluation of Targeted Incentives to Learn in India,” Mimeo, MIT.

Besley, T., Coate, S. (1992) "Workfare Versus Welfare: Incentive Arguments for Work Requirements in Poverty-Alleviation Programs," American Economic Review, 82(1), 249-261.

Bettinger, E., Slonim, R. (2007) “Patience among children,” Journal of Public Economics, 9, 343-363.

Bobonis, G. J. (2009) "Is the Allocation of Resources within the Household Efficient? New Evidence from a Randomized Experiment," Journal of Political Economy, 117(3), 453-503.

Bobonis, G. J., Finan, F. (2009) "Neighborhood Peer Effects in Secondary School Enrollment Decisions," Review of Economics and Statistics, 91 (4), 695-716.

Bourguignon, F., Ferreira, F. H. G., Leite, P. G. (2003) "Conditional Cash Transfers, Schooling, and Child Labor: Micro-Simulating Brazil's Bolsa Escola Program,” World Bank Economic Review, 17(2), 229-254.

Browning, M., Chiappori, P. A. (1998) "Efficient Intra-Household Allocations: A General Characterization and Empirical Tests," Econometrica, 66(6), 1241-78.

Bursztyn, L. (2010) "Electoral Incentives and Public Education Spending: Evidence from Brazil," Mimeo, Harvard University.

Card, D. E. (1995) "Using Geographic Variation in College Proximity to Estimate the Return to Schooling." In Christofides, L.N., Grant, E. K., Swidinskym R. (Eds), Aspects of Labor Market Behaviour: Essays in Honour of John Vanderkamp, University of Toronto Press, Toronto.

Card, D. E. (1999) “The Causal Effect of Education on Earnings.” In Ashenfelter, O., Card, D. (Eds) , Handbook of Labor Economics Volume 3A, Elsevier, Amsterdam. 
Card, D. E. (2001) "Estimating the Return to Schooling: Progress on Some Persistent Econometric Problems," Econometrica, 69(5), 1127-1160.

Cardoso, E., Portela Souza, A. (2004) "The Impact of Cash Transfers on Child Labor and School Attendance in Brazil," Mimeo, Vanderbilt University.

Cherchye, L., De Rock, B., Vermeulen, F. (2009) "Opening the Black Box of Intrahousehold Decision Making: Theory and Nonparametric Empirical Tests of General Collective Consumption Models," Journal of Political Economy, 117(6), 1074-1104.

Chiappori, P. A. (1992) “Collective Labor Supply and Welfare,” Journal of Political Economy, 100(3), 437-67.

Cunha, F., Heckman, J. (2007) “The Technology of Skill Formation," American Economic Review, 97(2), 3147.

de Janvry, A., Finan, F., Sadoulet, E. (2007) "Local Governance and Efficiency of Conditional Cash Transfer Programs: Bolsa Escola in Brazil," University of California at Berkeley.

de Janvry, A., Finan, F., Sadoulet, E., Vakis, R. (2006) "Can conditional cash transfer programs serve as safety nets in keeping children at school and from working when exposed to shocks?," Journal of Development Economics, 79, 349-373.

de Janvry, A., Sadoulet. E. (2006) "When to Use a CCT Versus a CT Approach?," Mimeo, University of California at Berkeley.

Dinkelman, T., Martínez, C. A. (2011) "Investing in schooling in Chile: The role of information about financial aid for higher education,” Princeton University, Center for Economic Policy Studies Working Paper 1296.

Dominitz, J., Manski, C. F. (1996) "Eliciting Student Expectations of the Returns to Schooling," Journal of Human Resources, 31(1), 1-26.

Duflo, E. (2003) "Grandmothers and granddaughters: Old-age pensions and intrahousehold allocation in South Africa," World Bank Economic Review, 17(1), 1-25.

Duflo, E., Udry, C. (2004) "Intrahousehold Resource Allocation in Cote d'Ivoire: Social Norms, Separate Accounts and Consumption Choices," NBER Working Paper 10498.

Edmonds, E. V. (2006) “Child Labor and Schooling Responses to Anticipated Income in South Africa," Journal of Development Economics, 81(2), 386-414.

Edmonds, E. V., Schady, N. (2009) “Poverty Alleviation and Child Labor,” NBER Working Paper 15345.

Fiszbein, A., Schady, N. (with Ferreira, F. H. G., Grosh, M., Kelleher, N., Olinto, P., Skouİas, E.) (2009) Conditional cash transfers: reducing present and future poverty. World Bank Policy Research Report.

Gahvari, F., Mattos, E. (2007) "Conditional Cash Transfers, Public Provision of Private Goods, and Income Redistribution," American Economic Review, 97(1), 491-502.

Gatti, R. (2005) “Family Altruism and Incentives,” Scandinavian Journal of Economics, 107(1), 67-81.

Glewwe, P., Kassouf, A. L. (2008) “The Impact of the Bolsa Escola/Familia Conditional Cash Transfer Program on Enrollment, Grade Promotion and Drop out Rates in Brazil,” Mimeo, University of Minnesota. 
Glewwe. P., Olinto P. (2004) "Evaluating the impact of conditional cash transfers on schooling: An experimental analysis of Honduras' PRAF program," Mimeo, University of Minnesota.

Goldin, C., Katz, L. F. (2008) "Mass Secondary Schooling and the State: The Role of State Compulsion in the High School Movement,” NBER Working Paper 10075, 2003; revised 2008.

Goldin, C., Katz, L. F. (2008) The Race Between Education and Technology, Harvard University Press, Cambidge, MA.

Hanushek, E. A., Woessmann, L. (2009) "Schooling, Cognitive Skills, and the Latin American Growth Puzzle," CESifo Working Paper Number 2667.

Harrison, G. W., List, J. A. (2004) “Field Experiments,” Journal of Economic Literature, 42, 1009-1055.

Hastings, J. S., Van Weelden, R., Weinstein, J. (2007) "Preferences, Information and Parental Choice Behavior in Public School Choice,” NBER Working Paper 12995.

Holt, C., Laury, S. (2002) "Risk Aversion and Incentive Effects," American Economic Review, 92(5), 16441655 .

Jackson, C. K. (2008). "A little now for a lot later: a look at the Texas Advanced Placement Incentive Program," Mimeo, Cornell University.

Jensen, R. (2010) “The (Perceived) Returns to Education and the Demand for Schooling," Quarterly Journal of Economics, 125(2), 515-548.

Katz, L. F., Kling, J. R., Liebman, J. B. (2001) "Moving to Opportunity in Boston: Early Results of a Randomized Mobility Experiment," Quarterly Journal of Economics, 116(2), 607-654.

Kling, J. R., Ludwig, J., Katz, L. F. (2005) "Neighborhood Effects on Crime for Female and Male Youth: Evidence from a Randomized Housing Voucher Experiment," Quarterly Journal of Economics, 120(1): 87130.

Kremer, M., Miguel, E., Thornton, R. (2004) “Incentives to learn,” NBER Working Paper 10971.

Krueger, A. B., Lindahl, M. (2001) "Education for Growth: Why and For Whom?," Journal of Economic Literature, 39, 1101-1136.

Kruger, D. I. (2007) “Coffee Production Effects on Child Labor and Schooling in Rural Brazil," Journal of Development Economics, 82, 448-463.

Lleras-Muney, A. (2005) "The Relationship Between Education and Adult Mortality in the United States," Review of Economic Studies, 72, 189-221.

Li, H., Rosenzweig, M., Zhang, J. (2010) "Altruism, Favoritism, and Guilt in the Allocation of Family Resources: Sophie's Choice in Mao's Mass Send Down Movement," Journal of Political Economy, 110(1), $1-38$.

List, J. A. (2008) “Homo Experimentalis Evolves,” Science, 321(5886): 207-208.

Lizzeri, A., Siniscalchi, M. (2008) "Parental Guidance and Supervised Learning," Quarterly Journal of Economics, 123(3), 1161-1195. 
Lochner, L. J., Moretti, E. (2004) "The Effect of Education on Crime: Evidence from Prison Inmates Arrests, and Self-Reports," American Economic Review, 94, 155-189.

Milligan, K., Moretti, E., Oreopoulos, P. (2004) "Does Education Improve Citizenship? Evidence From The United States And The United Kingdom,” Journal of Public Economics, 88, 1667-1695.

Moffitt, R. (1992) "Incentive effects of the U.S. welfare system: A review," Journal of Economic Literature, $30,1-60$.

Parker, S., Rubalcava, L., Teruel, G. (2008) "Evaluating Conditional Schooling and Health Programs." In Schultz, T. P., Strauss, J. (Eds.), Handbook of Development Economics, Volume 4. Elsevier, Amsterdam.

PNAD (2001, 2006, 2007, 2008) Pesquisa Nacional por Amostra de Domicilios, Instituto Brasileiro de Geografia e Estatistica. Rio de Janeiro, RJ.

Rangel, M. A. (2006) "Alimony Rights and Intrahousehold Allocation of Resources: Evidence from Brazil," Economic Journal, 116 (513), 627-658.

Rosenzweig, M., Wolpin, K. (1994) “Transfers to young women and their children," American Economic Review, 84, 1195-1212.

Schultz, T. P. (2004) "School subsidies for the poor: Evaluating the Mexican Progresa poverty Program," Journal of Development Economics, 74(1), 199-250.

Spence, M. (1973) “Job Market Signaling,” Quarterly Journal of Economics, 87(3), 355-374.

Weinberg, B. (2001) "An incentive model of the effect of parental income on children," Journal of Political Economy, 109(2), 266-280.

Zeckhauser, R. (1971) “Optimal Mechanisms for Income Transfer,” American Economic Review, 61(3), 324334. 


\section{Figures and tables}

Figure 1: Cumulative probability for the required unconditional transfer (censored threshold) in the Baseline treatment group

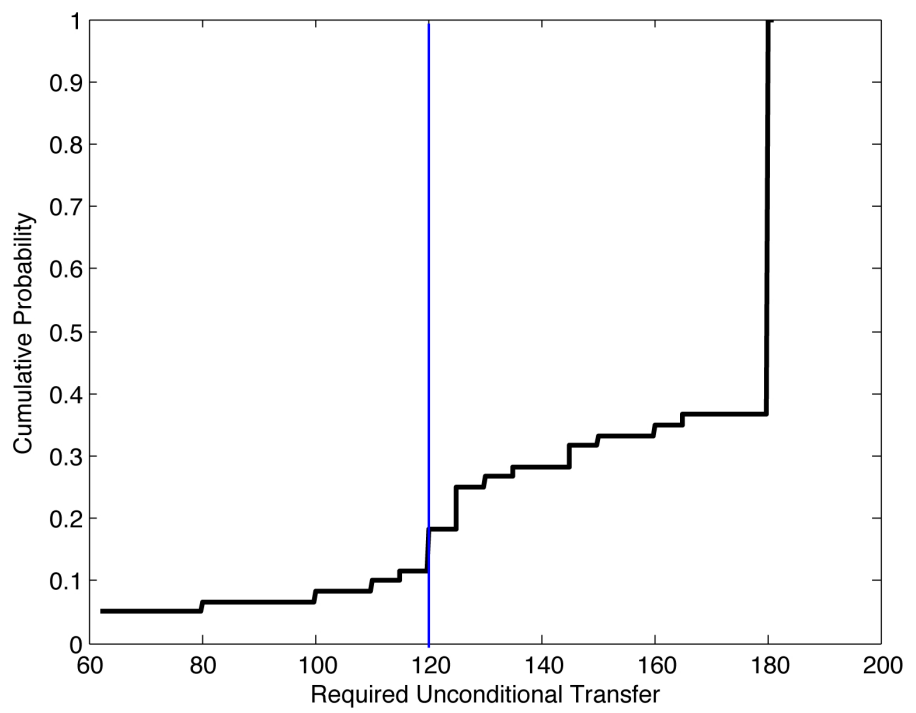

Figure 2: Cumulative probability for the required unconditional transfer (censored threshold): Baseline and Don't Tell treatment groups (with $95 \%$ bootstrap confidence intervals - 1,000 bootstrap samples)

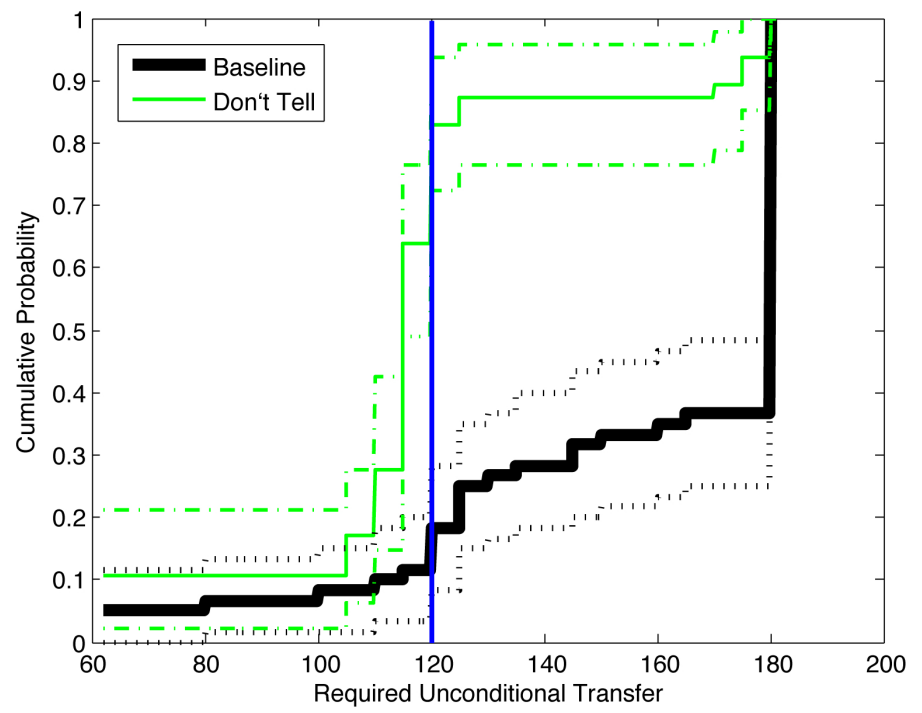

Notes: We re-sampled with replacement from the empirical distribution 1,000 times. From these 1,000 bootstrap samples, we computed the confidence intervals for each point on the cumulative distribution. 
Figure 3: Cumulative probability for the required unconditional transfer (censored threshold): Baseline and Text message treatment groups (with $95 \%$ bootstrap confidence intervals - 1,000 bootstrap samples)

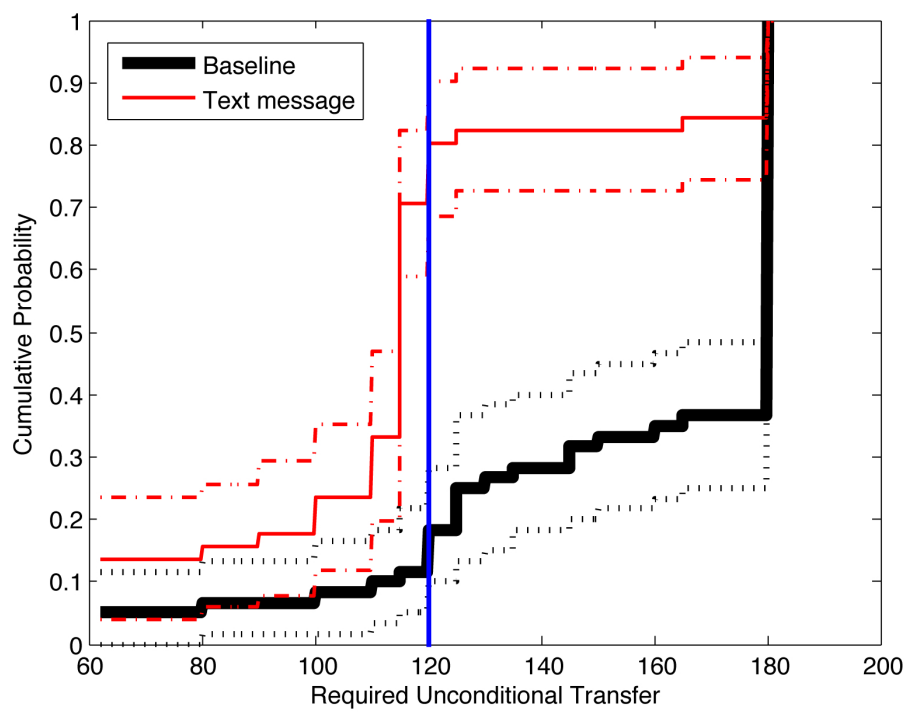

Notes: We re-sampled with replacement from the empirical distribution 1,000 times. From these 1,000 bootstrap samples, we computed the confidence intervals for each point on the cumulative distribution.

Figure 4: Cumulative probability for the required unconditional transfer (censored threshold): Baseline and Non-classroom treatment groups (with 95\% bootstrap CI - 1000 bootstrap samples)

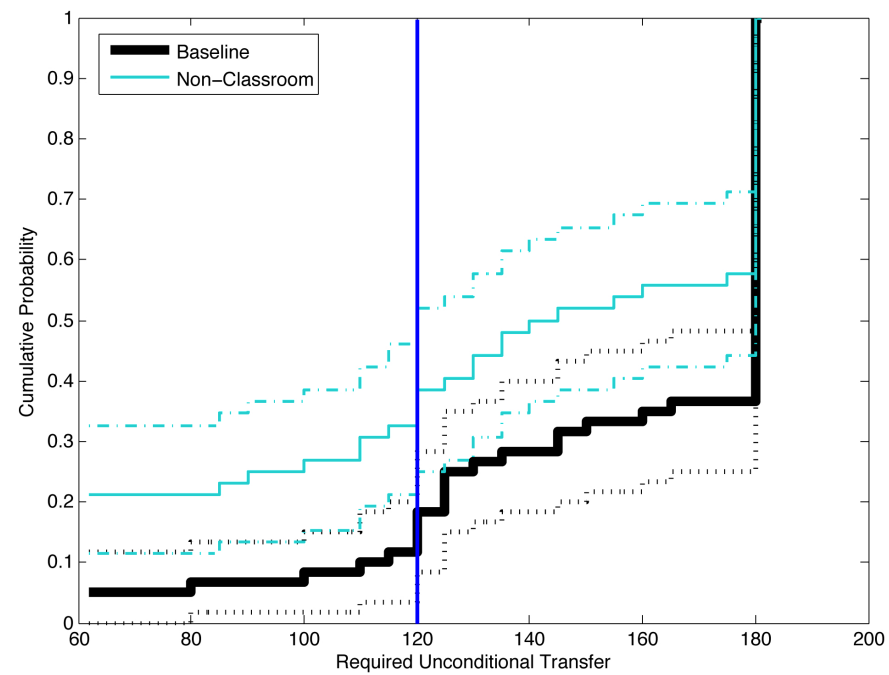

Notes: We re-sampled with replacement from the empirical distribution 1,000 times. From these 1,000 bootstrap samples, we computed the confidence intervals for each point on the cumulative distribution. 
Table 1: Treatments "roadmap"

Baseline treatment $(\mathrm{N}=60)$

Type of conditionality: $85 \%$ attendance of classes

Additional features: -

Does the child know the choice? YES

Research question: Are parents willing to pay for the conditionality?

Implication: If so, evidence of parental demand for a device to stimulate school attendance

Don't Tell treatment $(\mathrm{N}=47)$

Type of conditionality: $85 \%$ attendance of classes

Additional features: -

Does the child know the choice? NO

Research question: Do parents need the conditionality to control the child?

Implication: If so, evidence of parent-child conflict about school attendance

Text message treatment $(\mathrm{N}=51)$

Type of conditionality: $85 \%$ attendance of classes

Additional features: Free text message when child misses class (for any choice)

Does the child know the choice? YES

Research question: Do parents demand a monitoring device to control the child?

Implication: If so, evidence that parental control is reduced by moral hazard problem

Non-classroom treatment $(\mathrm{N}=52)$

Type of conditionality: $85 \%$ attendance in no-class shift

Additional features: -

Does the child know the choice? YES

Research question: Are parents still willing to pay for a conditionality on being at school but not in class?

Implication: If so, evidence that demand for schooling is for more than skills provision 
Table 2: Means of observables across treatments

\begin{tabular}{|c|c|c|c|c|}
\hline \multirow[b]{2}{*}{ Variable (mean) } & \multicolumn{4}{|c|}{ Treatment } \\
\hline & $\begin{array}{c}\text { Baseline } \\
(\mathrm{N}=60)\end{array}$ & $\begin{array}{l}\text { Don't Tell } \\
(\mathrm{N}=47)\end{array}$ & $\begin{array}{l}\text { Text message } \\
(\mathrm{N}=51)\end{array}$ & $\begin{array}{c}\text { Non-classroom } \\
(\mathrm{N}=52)\end{array}$ \\
\hline Age (parent) & $\begin{array}{l}40.58 \\
(7.33)\end{array}$ & $\begin{array}{c}41.23 \\
(10.29)\end{array}$ & $\begin{array}{l}38.47^{*} \\
(5.65)\end{array}$ & $\begin{array}{l}40.10 \\
(6.70)\end{array}$ \\
\hline Age (child) & $\begin{array}{l}14.22 \\
(0.81)\end{array}$ & $\begin{array}{l}14.28 \\
(0.74)\end{array}$ & $\begin{array}{l}14.06 \\
(0.98)\end{array}$ & $\begin{array}{l}14.29 \\
(0.87)\end{array}$ \\
\hline Male parent & $\begin{array}{c}0.03 \\
(0.18)\end{array}$ & $\begin{array}{c}0.04 \\
(0.20)\end{array}$ & $\begin{array}{c}0.00 \\
(0.00)\end{array}$ & $\begin{array}{c}0.08 \\
(0.27)\end{array}$ \\
\hline Male child & $\begin{array}{c}0.44 \\
(0.50)\end{array}$ & $\begin{array}{c}0.38 \\
(0.49)\end{array}$ & $\begin{array}{c}0.42 \\
(0.50)\end{array}$ & $\begin{array}{c}0.48 \\
(0.50)\end{array}$ \\
\hline Married & $\begin{array}{c}0.50 \\
(0.50)\end{array}$ & $\begin{array}{c}0.57 \\
(0.50)\end{array}$ & $\begin{array}{c}0.59 \\
(0.50)\end{array}$ & $\begin{array}{c}0.42 \\
(0.50)\end{array}$ \\
\hline Single & $\begin{array}{c}0.25 \\
(0.44)\end{array}$ & $\begin{array}{c}0.17 \\
(0.38)\end{array}$ & $\begin{array}{c}0.18 \\
(0.39)\end{array}$ & $\begin{array}{c}0.27 \\
(0.45)\end{array}$ \\
\hline Divorced & $\begin{array}{c}0.25 \\
(0.44)\end{array}$ & $\begin{array}{c}0.26 \\
(0.44)\end{array}$ & $\begin{array}{c}0.24 \\
(0.43)\end{array}$ & $\begin{array}{c}0.31 \\
(0.47)\end{array}$ \\
\hline Log $\mathrm{HH}$ income & $\begin{array}{c}6.24 \\
(0.49)\end{array}$ & $\begin{array}{c}6.23 \\
(0.56)\end{array}$ & $\begin{array}{c}6.23 \\
(0.61)\end{array}$ & $\begin{array}{l}6.09 * \\
(0.45)\end{array}$ \\
\hline Employed parent & $\begin{array}{c}0.47 \\
(0.50)\end{array}$ & $\begin{array}{c}0.43 \\
(0.50)\end{array}$ & $\begin{array}{c}0.53 \\
(0.50)\end{array}$ & $\begin{array}{c}0.56 \\
(0.50)\end{array}$ \\
\hline Employed spouse & $\begin{array}{c}0.32 \\
(0.47)\end{array}$ & $\begin{array}{c}0.34 \\
(0.48)\end{array}$ & $\begin{array}{l}0.47 * \\
(0.50)\end{array}$ & $\begin{array}{c}0.15^{* *} * \\
(0.36)\end{array}$ \\
\hline Catholic & $\begin{array}{c}0.52 \\
(0.50)\end{array}$ & $\begin{array}{c}0.55 \\
(0.50)\end{array}$ & $\begin{array}{c}0.55 \\
(0.50)\end{array}$ & $\begin{array}{c}0.58 \\
(0.50)\end{array}$ \\
\hline Protestant & $\begin{array}{c}0.40 \\
(0.49)\end{array}$ & $\begin{array}{c}0.38 \\
(0.49)\end{array}$ & $\begin{array}{c}0.41 \\
(0.50)\end{array}$ & $\begin{array}{c}0.40 \\
(0.50)\end{array}$ \\
\hline No religion & $\begin{array}{c}0.05 \\
(0.22)\end{array}$ & $\begin{array}{c}0.02 \\
(0.15)\end{array}$ & $\begin{array}{c}0.04 \\
(0.20)\end{array}$ & $\begin{array}{c}0.02 \\
(0.14)\end{array}$ \\
\hline Beta (parent) ${ }^{a}$ & $\begin{array}{c}1.00 \\
(0.32)\end{array}$ & $\begin{array}{c}0.93 \\
(0.19)\end{array}$ & $\begin{array}{c}1.01 \\
(0.32)\end{array}$ & $\begin{array}{l}1.08 \\
(0.44)\end{array}$ \\
\hline Beta (child) & $\begin{array}{c}1.14 \\
(0.53)\end{array}$ & $\begin{array}{l}0.93 * * \\
(0.20)\end{array}$ & $\begin{array}{c}1.00 \\
(0.34)\end{array}$ & $\begin{array}{l}0.97 * * \\
(0.13)\end{array}$ \\
\hline Delta (parent) ${ }^{b}$ & $\begin{array}{c}0.76 \\
(0.24)\end{array}$ & $\begin{array}{c}0.79 \\
(0.21)\end{array}$ & $\begin{array}{l}0.67 * * \\
(0.22)\end{array}$ & $\begin{array}{c}0.69 \\
(0.25)\end{array}$ \\
\hline Delta (child) & $\begin{array}{c}0.73 \\
(0.25)\end{array}$ & $\begin{array}{l}0.83^{* *} \\
(0.16)\end{array}$ & $\begin{array}{c}0.78 \\
(0.18)\end{array}$ & $\begin{array}{c}0.79 \\
(0.25)\end{array}$ \\
\hline Higher show-up fee & $\begin{array}{c}0.20 \\
(0.40)\end{array}$ & $\begin{array}{c}0.32 \\
(0.47)\end{array}$ & $\begin{array}{c}0.22 \\
(0.42)\end{array}$ & $\begin{array}{c}0.13 \\
(0.34)\end{array}$ \\
\hline Years of schooling (parent) & $\begin{array}{c}7.12 \\
(3.22)\end{array}$ & $\begin{array}{c}6.34 \\
(3.42)\end{array}$ & $\begin{array}{c}7.18 \\
(3.01)\end{array}$ & $\begin{array}{c}6.62 \\
(2.84)\end{array}$ \\
\hline Years of schooling (child) & $\begin{array}{c}6.59 \\
(1.13)\end{array}$ & $\begin{array}{l}7.02 * \\
(1.24)\end{array}$ & $\begin{array}{c}6.84 \\
(1.09)\end{array}$ & $\begin{array}{c}6.54 \\
(1.23)\end{array}$ \\
\hline Number of children in $\mathrm{HH}$ & $\begin{array}{c}3.65 \\
(1.86)\end{array}$ & $\begin{array}{c}3.74 \\
(1.69)\end{array}$ & $\begin{array}{c}3.63 \\
(1.68)\end{array}$ & $\begin{array}{c}3.27 \\
(1.85)\end{array}$ \\
\hline More than one child earning Bolsa & $\begin{array}{c}0.52 \\
(0.50)\end{array}$ & $\begin{array}{c}0.54 \\
(0.50)\end{array}$ & $\begin{array}{c}0.71 * * \\
(0.46)\end{array}$ & $\begin{array}{c}0.60 \\
(0.49)\end{array}$ \\
\hline Black parent ${ }^{c}$ & $\begin{array}{c}0.28 \\
(0.45)\end{array}$ & $\begin{array}{c}0.19 \\
(0.40)\end{array}$ & $\begin{array}{c}0.20 \\
(0.40)\end{array}$ & $\begin{array}{c}0.17 \\
(0.38)\end{array}$ \\
\hline Mixed race parent & $\begin{array}{c}0.57 \\
(0.50)\end{array}$ & $\begin{array}{c}0.57 \\
(0.50)\end{array}$ & $\begin{array}{c}0.57 \\
(0.50)\end{array}$ & $\begin{array}{c}0.62 \\
(0.49)\end{array}$ \\
\hline White parent & $\begin{array}{c}0.13 \\
(0.34)\end{array}$ & $\begin{array}{c}0.21 \\
(0.41)\end{array}$ & $\begin{array}{c}0.24 \\
(0.43)\end{array}$ & $\begin{array}{c}0.19 \\
(0.40)\end{array}$ \\
\hline Black child & $\begin{array}{c}0.28 \\
(0.45)\end{array}$ & $\begin{array}{c}0.19 \\
(0.40)\end{array}$ & $\begin{array}{c}0.20 \\
(0.40)\end{array}$ & $\begin{array}{c}0.17 \\
(0.38)\end{array}$ \\
\hline Mixed race child & $\begin{array}{c}0.57 \\
(0.50)\end{array}$ & $\begin{array}{c}0.57 \\
(0.50)\end{array}$ & $\begin{array}{c}0.57 \\
(0.50)\end{array}$ & $\begin{array}{c}0.62 \\
(0.49)\end{array}$ \\
\hline White child & $\begin{array}{c}0.13 \\
(0.34)\end{array}$ & $\begin{array}{c}0.21 \\
(0.41)\end{array}$ & $\begin{array}{c}0.24 \\
(0.43)\end{array}$ & $\begin{array}{c}0.19 \\
(0.40)\end{array}$ \\
\hline
\end{tabular}

Notes: We display the means and standard deviations across treatments of the covariates used in the main regressions. We perform t-tests of equality in means, comparing the means of each variable in each treatment to the ones in the Baseline treatment. * $10 \%$ significant difference (for the mean in the treatment group when compared to the mean in the Baseline group). $* * 5 \%$ significant. We also perform F-tests that the means are equal across all four treatments. Of all 28 variables, we only reject the null hypothesis for four variables (Beta (child), Delta (child), Delta (parent) and Employed spouse. ${ }^{a}$ Beta refers to the time-inconsistency discount factor. it is the ratio between the time-discount factor of now vs one week and the discount factor of one week vs two weeks. Therefore beta different from one refers to time-inconsistent preferences.36Delta refers to the discount factor of one vs two weeks estimated in the experiment. (For a discussion on the construction of Beta and Delta see the Supplemental Appendix. ${ }^{c}$ Race is self-reported. 


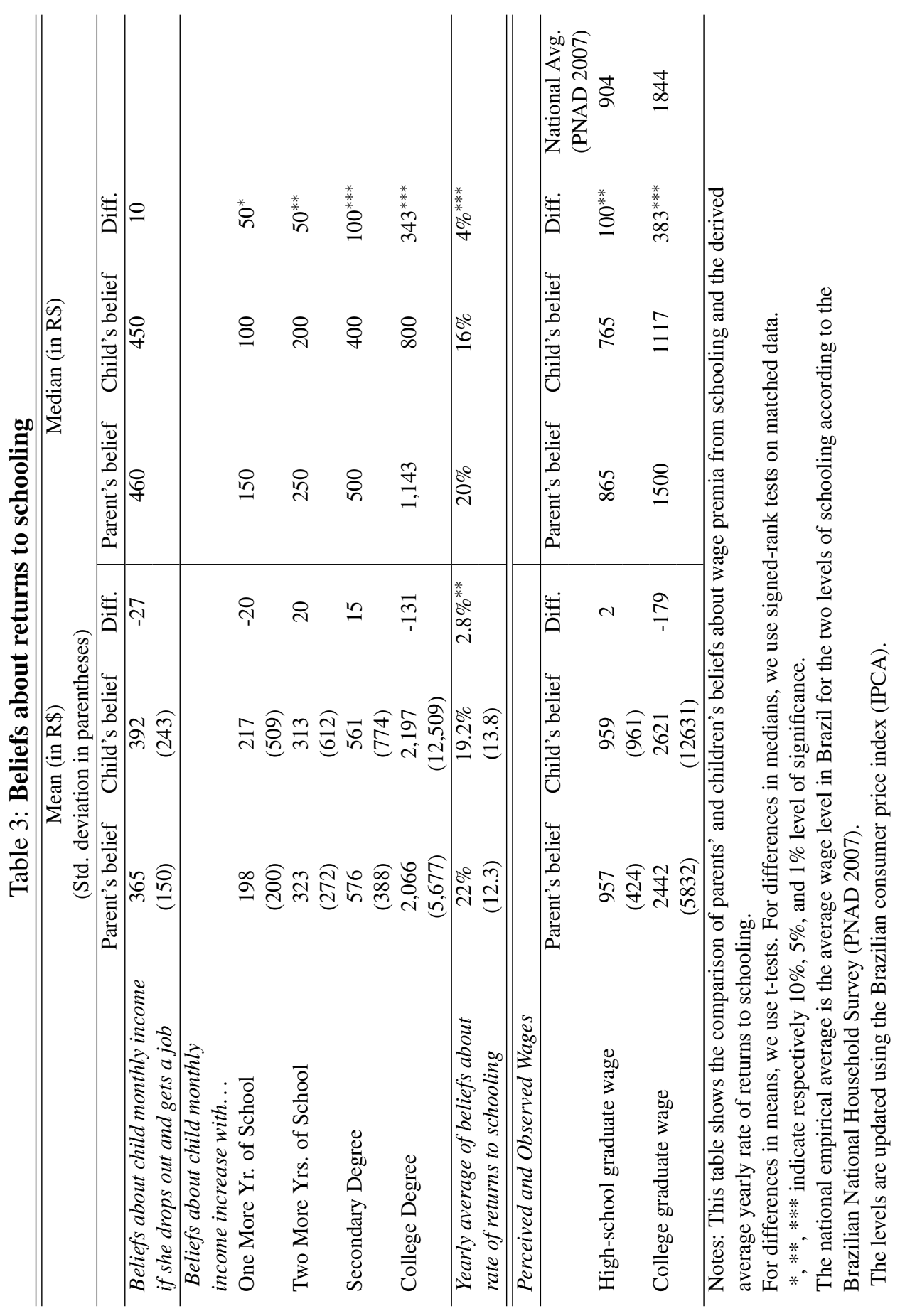



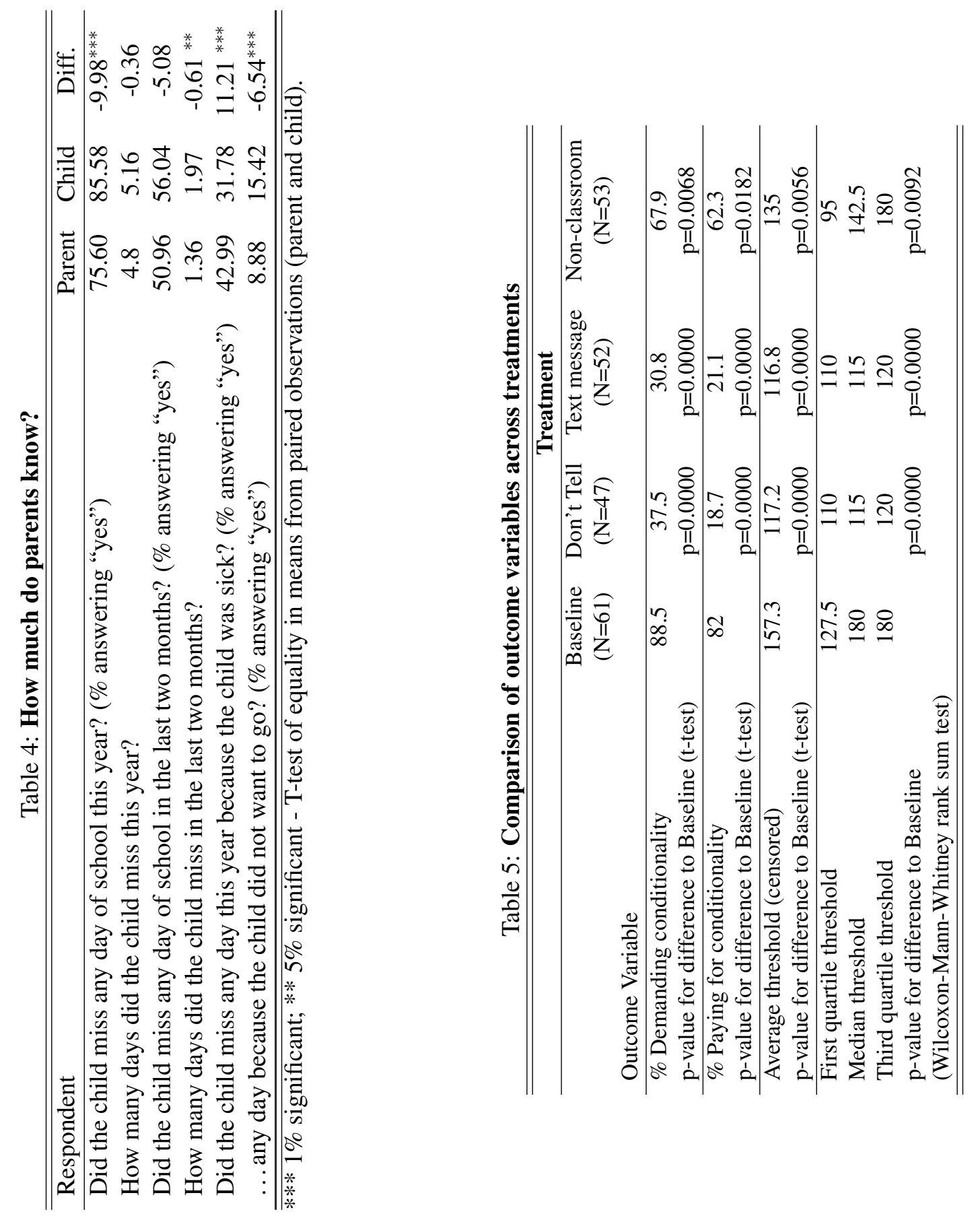


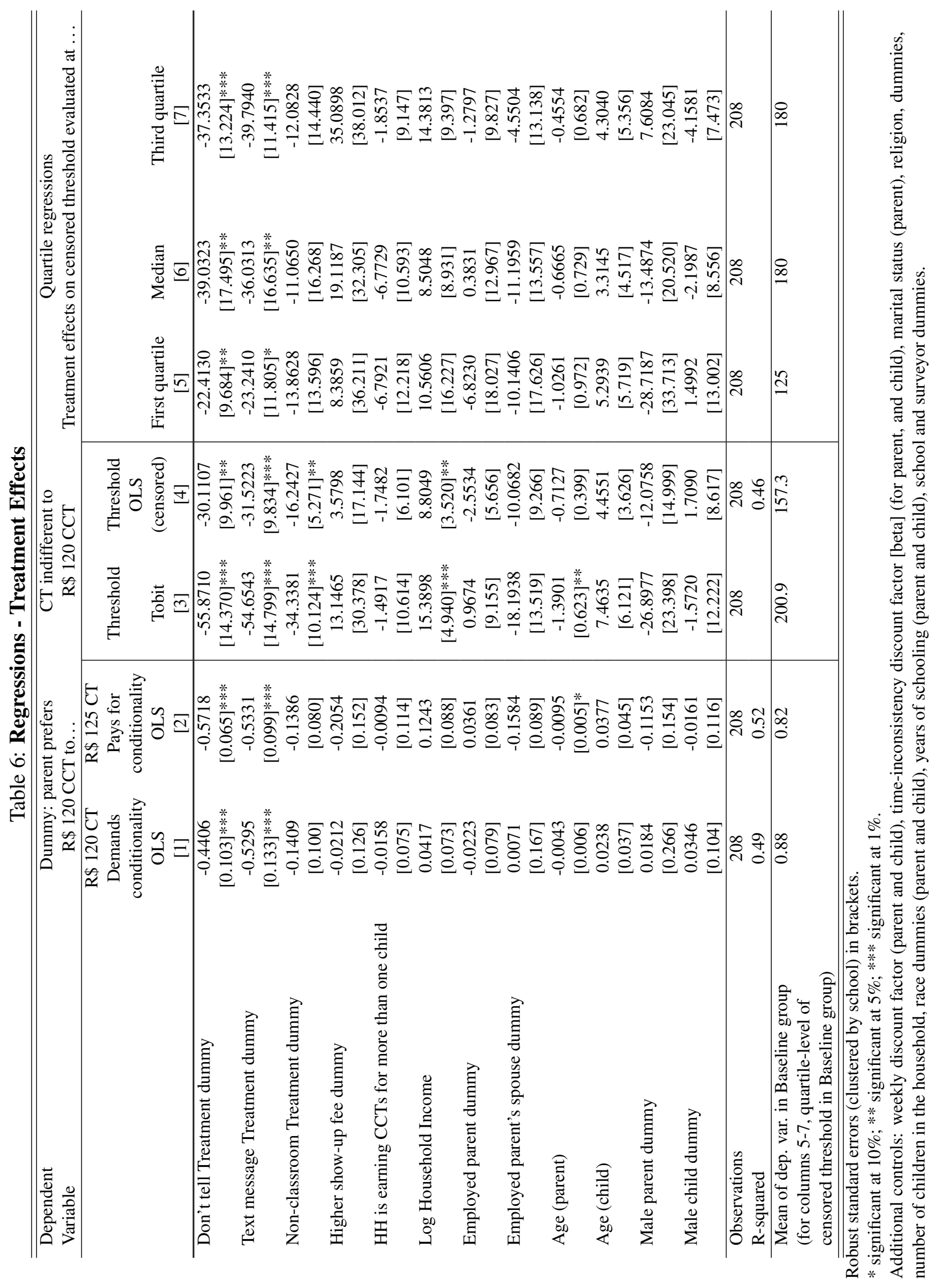


Table 7: Text message Treatment Interactions: How much do you think you know about what your child is doing?

\begin{tabular}{|c|c|c|c|c|c|}
\hline \multirow[t]{2}{*}{$\begin{array}{l}\text { Dependent } \\
\text { Variable }\end{array}$} & \multicolumn{2}{|c|}{$\begin{array}{l}\text { Dummy: parent prefers } \\
\text { R\$ } 120 \text { CCT to... }\end{array}$} & \multicolumn{2}{|c|}{$\begin{array}{l}\text { CT indifferent to } \\
\mathrm{R} \$ 120 \mathrm{CCT}\end{array}$} & $\begin{array}{l}\text { Treatment effects on censored threshold } \\
\text { evaluated at median }\end{array}$ \\
\hline & $\begin{array}{c}\text { R\$ } 120 \mathrm{CT} \\
\text { Demands } \\
\text { conditionality } \\
\text { OLS } \\
{[1]}\end{array}$ & $\begin{array}{c}\mathrm{R} \$ 125 \mathrm{CT} \\
\text { Pays for } \\
\text { conditionality } \\
\text { OLS } \\
{[2]}\end{array}$ & $\begin{array}{l}\text { Threshold } \\
\text { Tobit } \\
\text { [3] }\end{array}$ & $\begin{array}{l}\text { Threshold } \\
\text { OLS } \\
\text { (censored) } \\
{[4]}\end{array}$ & $\begin{array}{l}\text { Threshold } \\
\text { Median } \\
\text { regression } \\
\text { [5] }\end{array}$ \\
\hline Treatment effect & $\begin{array}{c}-0.5325 \\
{[0.130]^{* * *}}\end{array}$ & $\begin{array}{c}-0.5396 \\
{[0.103]^{* * *}}\end{array}$ & $\begin{array}{c}-54.3245 \\
{[15.064]^{* * *}}\end{array}$ & $\begin{array}{c}-31.6620 \\
{[9.922]^{* * * *}}\end{array}$ & $\begin{array}{c}-41.1995 \\
{[12.681]^{* * *}}\end{array}$ \\
\hline $\begin{array}{l}\text { How much do you know? } \\
\text { (standardized measure) } \\
\text { Interaction term }\end{array}$ & $\begin{array}{c}-0.0239 \\
{[0.034]} \\
0.0457 \\
{[0.056]}\end{array}$ & $\begin{array}{c}-0.0478 \\
{[0.048]} \\
0.0872 \\
{[0.046]^{*}}\end{array}$ & $\begin{array}{c}-3.9448 \\
{[4.639]} \\
11.5839 \\
{[4.415]^{* * *}}\end{array}$ & $\begin{array}{c}-2.7337 \\
{[3.154]} \\
6.8532 \\
{[2.733]^{* *}}\end{array}$ & $\begin{array}{c}-3.5383 \\
{[6.819]} \\
1.5701 \\
{[10.654]}\end{array}$ \\
\hline $\begin{array}{l}\text { Observations } \\
\text { R-squared }\end{array}$ & $\begin{array}{c}208 \\
0.491\end{array}$ & $\begin{array}{c}208 \\
0.528\end{array}$ & 208 & $\begin{array}{c}208 \\
0.460\end{array}$ & 208 \\
\hline
\end{tabular}

Robust standard errors (clustered by school) in brackets. * significant at 10\%; ** significant at 5\%; *** significant at $1 \%$.

We display the results from the interaction of the Text message treatment dummy with the measure of parental beliefs about observability, where we use a standardized measure (zero mean and unit variance) of the 0 to 5-scale observability variable. Additional controls: Don't Tell and Non-classroom treatment dummies, higher show-up fee dummy, log of household income, age (parent and child), male indicator (parent and child), weekly discount factor (parent and child), time-inconsistency discount factor [beta] (for parent, and child), marital status (parent), employed parent dummy, employed spouse dummy, religion, dummies, number of children in the household, dummy on whether the household is earning CCTs for more than one child, race dummies (parent and child), years of schooling (parent and child), school and surveyor dummies. 
Table 8: Non-classroom Treatment Interactions: How much do you think you know about what your child is doing?

\begin{tabular}{|c|c|c|c|c|c|}
\hline \multirow[t]{2}{*}{$\begin{array}{l}\text { Dependent } \\
\text { Variable }\end{array}$} & \multicolumn{2}{|c|}{$\begin{array}{l}\text { Dummy: parent prefers } \\
\text { R } \$ 120 \text { CCT to... }\end{array}$} & \multicolumn{2}{|c|}{$\begin{array}{l}\text { CT indifferent to } \\
\mathrm{R} \$ 120 \mathrm{CCT}\end{array}$} & $\begin{array}{c}\text { Treatment effects on censored threshold } \\
\text { evaluated at median }\end{array}$ \\
\hline & $\begin{array}{c}\text { R\$ } 120 \mathrm{CT} \\
\text { Demands } \\
\text { conditionality } \\
\text { OLS } \\
\text { [1] }\end{array}$ & $\begin{array}{c}\mathrm{R} \$ 125 \mathrm{CT} \\
\text { Pays for } \\
\text { conditionality } \\
\text { OLS } \\
{[2]}\end{array}$ & $\begin{array}{l}\text { Threshold } \\
\text { Tobit } \\
\text { [3] }\end{array}$ & $\begin{array}{c}\text { Threshold } \\
\text { OLS } \\
\text { (censored) } \\
\text { [4] }\end{array}$ & $\begin{array}{l}\text { Threshold } \\
\text { Median } \\
\text { regression } \\
\text { [5] }\end{array}$ \\
\hline Treatment effect & $\begin{array}{l}-0.1442 \\
{[0.101]}\end{array}$ & $\begin{array}{l}-0.1459 \\
{[0.086]}\end{array}$ & $\begin{array}{c}-33.5283 \\
{[10.341]^{* * *}}\end{array}$ & $\begin{array}{l}-16.4864 \\
{[5.445]^{* *}}\end{array}$ & $\begin{array}{c}-21.7156 \\
{[10.863]^{* *}}\end{array}$ \\
\hline $\begin{array}{l}\text { How much do you know? } \\
\text { (standardized measure) } \\
\text { Interaction term }\end{array}$ & $\begin{array}{c}0.0207 \\
{[0.031]} \\
-0.1239 \\
{[0.068]^{*}}\end{array}$ & $\begin{array}{c}0.0078 \\
{[0.032]} \\
-0.1222 \\
{[0.054]^{* *}}\end{array}$ & $\begin{array}{c}5.8836 \\
{[4.277]} \\
-26.7042 \\
{[10.227]^{* * *}}\end{array}$ & $\begin{array}{c}2.6033 \\
{[2.795]} \\
-13.3478 \\
{[6.261]^{*}}\end{array}$ & $\begin{array}{c}0.8902 \\
{[3.030]} \\
-17.1937 \\
{[8.969]^{*}}\end{array}$ \\
\hline $\begin{array}{l}\text { Observations } \\
\text { R-squared }\end{array}$ & $\begin{array}{c}208 \\
0.498\end{array}$ & $\begin{array}{c}208 \\
0.531\end{array}$ & 208 & $\begin{array}{c}208 \\
0.470\end{array}$ & 208 \\
\hline
\end{tabular}

Robust standard errors (clustered by school) in brackets. * significant at 10\%; ** significant at 5\%; *** significant at $1 \%$.

We display the results from the interaction of the Non-classroom treatment dummy with the measure of parental beliefs about observability, where we use a standardized measure (zero mean and unit variance) of the 0 to 5 -scale observability variable. Additional controls: Don't Tell and Text message treatment dummies, higher show-up fee dummy, log of household income, age (parent and child), male indicator (parent and child), weekly discount factor (parent and child), time-inconsistency discount factor [beta] (for parent, and child), marital status (parent), employed parent dummy, employed spouse dummy, religion, dummies, number of children in the household, dummy on whether the household is earning CCTs for more than one child, race dummies (parent and child), years of schooling (parent and child), school and surveyor dummies. 
Table 9: Treatment Effects and Surveyors' Training

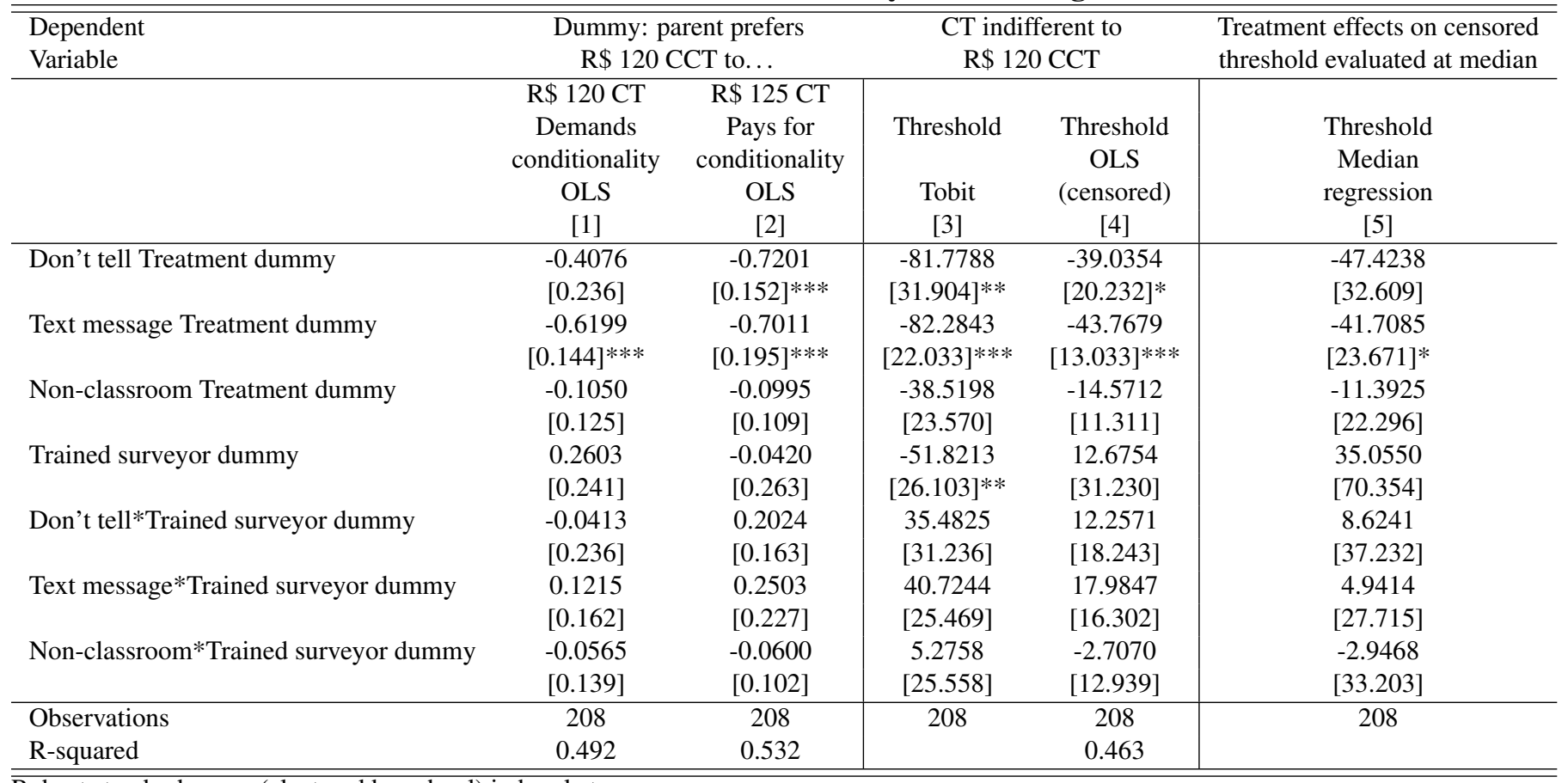

Robust standard errors (clustered by school) in brackets.

* significant at $10 \%$; ** significant at $5 \%$; *** significant at $1 \%$.

Additional controls: Higher show-up fee dummy, log of household income, age (parent and child), male indicator (parent and child), weekly discount factor (parent and child), time-inconsistency discount factor [beta] (for parent, and child), marital status (parent), employed parent dummy, employed spouse dummy, religion, dummies, number of children in the household, dummy on whether the household is earning CCTs for more than one child, race dummies (parent and child), years of schooling (parent and child), school and surveyor dummies. 
Table 10: Treatment Effects and Surveyors' Experience

(Experience is measured at each experimental session as the total number of interviews each surveyor has conducted prior to that session)

\begin{tabular}{|c|c|c|c|c|c|}
\hline $\begin{array}{l}\text { Dependent } \\
\text { Variable }\end{array}$ & \multicolumn{2}{|c|}{$\begin{array}{l}\text { Dummy: parent prefers } \\
\text { R\$ } 120 \text { CCT to... }\end{array}$} & \multicolumn{2}{|c|}{$\begin{array}{l}\text { CT indifferent to } \\
\mathrm{R} \$ 120 \mathrm{CCT}\end{array}$} & $\begin{array}{l}\text { Treatment effects on censored } \\
\text { threshold evaluated at median }\end{array}$ \\
\hline & $\begin{array}{c}\mathrm{R} \$ 120 \mathrm{CT} \\
\text { Demands } \\
\text { conditionality } \\
\text { OLS } \\
{[1]}\end{array}$ & $\begin{array}{c}\mathrm{R} \$ 125 \mathrm{CT} \\
\text { Pays for } \\
\text { conditionality } \\
\text { OLS } \\
{[2]}\end{array}$ & $\begin{array}{c}\text { Threshold } \\
\text { Tobit } \\
{[3]}\end{array}$ & $\begin{array}{c}\text { Threshold } \\
\text { OLS } \\
\text { (censored) } \\
{[4]}\end{array}$ & $\begin{array}{l}\text { Threshold } \\
\text { Median } \\
\text { regression } \\
\text { [5] }\end{array}$ \\
\hline Don't tell Treatment dummy & $\begin{array}{c}-0.3898 \\
{[0.118]^{* * *}}\end{array}$ & $\begin{array}{c}-0.6225 \\
{[0.125]^{* * *}}\end{array}$ & $\begin{array}{c}-67.4424 \\
{[16.183]^{* * *}}\end{array}$ & $\begin{array}{c}-30.1500 \\
{[11.613]^{* *}}\end{array}$ & $\begin{array}{c}-34.1758 \\
{[16.446]^{* *}}\end{array}$ \\
\hline Text message Treatment dummy & $\begin{array}{c}-0.7813 \\
{[0.180]^{* * *}}\end{array}$ & $\begin{array}{c}-0.6985 \\
{[0.148]^{* * *}}\end{array}$ & $\begin{array}{c}-86.8619 \\
{[27.852] * * *}\end{array}$ & $\begin{array}{c}-44.6443 \\
{[17.186]^{* *}}\end{array}$ & $\begin{array}{c}-44.1880 \\
{[13.708]^{* * *}}\end{array}$ \\
\hline Non-classroom Treatment dummy & $\begin{array}{c}-0.2481 \\
{[0.136]^{*}}\end{array}$ & $\begin{array}{l}-0.1777 \\
{[0.119]}\end{array}$ & $\begin{array}{c}-58.3168 \\
{[17.239] * * *}\end{array}$ & $\begin{array}{l}-23.1805 \\
{[8.886]^{* *}}\end{array}$ & $\begin{array}{l}-19.6086 \\
{[17.491]}\end{array}$ \\
\hline Surveyor experience & $\begin{array}{r}-0.0093 \\
{[0.017]}\end{array}$ & $\begin{array}{r}-0.0117 \\
{[0.018]}\end{array}$ & $\begin{array}{l}-2.2749 \\
{[2.457]}\end{array}$ & $\begin{array}{l}-0.9522 \\
{[1.884]}\end{array}$ & $\begin{array}{l}-0.5843 \\
{[1.449]}\end{array}$ \\
\hline Don't tell*Surveyor experience & $\begin{array}{r}-0.0078 \\
{[0.012]}\end{array}$ & $\begin{array}{l}0.0053 \\
{[0.014]}\end{array}$ & $\begin{array}{l}1.0083 \\
{[1.041]}\end{array}$ & $\begin{array}{l}-0.0699 \\
{[0.805]}\end{array}$ & $\begin{array}{r}-0.0891 \\
{[1.593]}\end{array}$ \\
\hline Text message*Surveyor experience & $\begin{array}{l}0.0218 \\
{[0.014]}\end{array}$ & $\begin{array}{l}0.0152 \\
{[0.012]}\end{array}$ & $\begin{array}{c}2.8589 \\
{[1.705]^{*}}\end{array}$ & $\begin{array}{l}1.1901 \\
{[1.202]}\end{array}$ & $\begin{array}{l}0.5757 \\
{[1.663]}\end{array}$ \\
\hline Non-classroom*Surveyor experience & $\begin{array}{l}0.0126 \\
{[0.008]}\end{array}$ & $\begin{array}{l}0.0059 \\
{[0.011]}\end{array}$ & $\begin{array}{c}2.5543 \\
{[1.315]^{*}}\end{array}$ & $\begin{array}{l}0.8555 \\
{[0.869]}\end{array}$ & $\begin{array}{c}1.1482 \\
{[1.448]}\end{array}$ \\
\hline $\begin{array}{l}\text { Observations } \\
\text { R-squared }\end{array}$ & $\begin{array}{c}208 \\
0.518\end{array}$ & $\begin{array}{c}208 \\
0.531\end{array}$ & 208 & $\begin{array}{c}208 \\
0.468\end{array}$ & 208 \\
\hline
\end{tabular}

Robust standard errors (clustered by school) in brackets.

* significant at $10 \%$; ** significant at $5 \%$; *** significant at $1 \%$.

Additional controls: Higher show-up fee dummy, log of household income, age (parent and child), male indicator (parent and child), weekly discount factor (parent and child), time-inconsistency discount factor [beta] (for parent, and child), marital status (parent), employed parent dummy, employed spouse dummy, religion, dummies, number of children in the household, dummy on whether the household is earning CCTs for more than one child, race dummies (parent and child), years of schooling (parent and child), school and surveyor dummies. 